\title{
RESEARCH
}

Open Access

\section{Exploring the factors affecting carbon and nutrient concentrations in tree biomass components in natural forests, forest plantations and short rotation forestry}

Roque Rodríguez-Soalleiro ${ }^{1 *}$ D , Cristina Eimil-Fraga ${ }^{1}$, Esteban Gómez-García ${ }^{2}$, Juan Daniel García-Villabrille ${ }^{3}$, Alberto Rojo-Alboreca ${ }^{3}$, Fernando Muñoz ${ }^{4}$, Nerea Oliveira ${ }^{5}$, Hortensia Sixto ${ }^{5}$ and César Pérez-Cruzado ${ }^{3}$

\begin{abstract}
Background: Coupling biomass models with nutrient concentrations can provide sound estimations of carbon and nutrient contents, enabling the improvement of carbon and nutrient balance in forest ecosystems. Although nutrient concentrations are often assumed to be constant for some species and specific tree components, at least in mature stands, the concentrations usually vary with age, site index and even with tree density. The main objective of this study was to evaluate the sources of variation in nutrient concentrations in biomass compartments usually removed during harvesting operations, covering a range of species and management conditions: semi-natural forest, conventional forest plantations and short rotation forestry (SRF). Five species (Betula pubescens, Quercus robur, Eucalyptus globulus, Eucalyptus nitens and Populus spp.) and 14 genotypes were considered. A total of 430 trees were sampled in 61 plots to obtain 6 biomass components: leaves, twigs, thin branches, thick branches, bark and wood. Aboveground leafless biomass was pooled together for poplar. The concentrations of $\mathrm{C}, \mathrm{N}, \mathrm{K}, \mathrm{P}, \mathrm{Ca}, \mathrm{Mg}, \mathrm{S}, \mathrm{Fe}, \mathrm{Mn}, \mathrm{Cu}, \mathrm{Zn}$ and $\mathrm{B}$ were measured and the total biomass of each sampled tree and plot were determined. The data were analysed using boosted regression trees and conventional techniques.
\end{abstract}

Results: The main sources of variation in nutrient concentrations were biomass component > > genotype (species) $\approx$ age > tree diameter. The concentrations of $\mathrm{Ca}, \mathrm{Mg}$ and $\mathrm{K}$ were most strongly affected by genotype and age. The concentrations of $\mathrm{P}, \mathrm{K}, \mathrm{Ca}, \mathrm{Mg}$, $\mathrm{S}$ and $\mathrm{Cu}$ in the wood component decreased with age, whereas $\mathrm{C}$ concentrations increased, with a trend to reach 50\% in the older trees. In the SRF, interamerican poplar and $P$. trichocarpa genotypes were comparatively more efficient in terms of $\mathrm{Ca}$ and $\mathrm{K}$ nutrient assimilation index (NAI) (+65-85\%) than eucalypts, mainly because leafless biomass can be removed. In the conventional eucalypt plantations (rotation 15 years), debarking the wood at logging (savings of $225 \%$ of $\mathrm{Ca}$ and $254 \%$ of Mg for E. globulus) or the use of selected genotypes (savings of $45 \%$ of P and $35 \%$ of $\mathrm{Ca}$ ) will provide wood at a relatively lower nutrient cost. Considering all the $E$. globulus genotypes together, the management for pulp with removal of debarked wood shows NAl values well above $(\times 1.7-\times 3.9)$ the ones found for poplar or eucalypt SRF and also higher $(\times 1.6-\times 4.0)$ than the ones found for oak and birch managed in medium or long rotations. The annual rates of nutrient removal were low in the native broadleaved species but the rates of available soil nutrients removed were high as compared to poplar or eucalypts. Management of native broadleaved species should consider nutrient stability through selection of the biomass compartments removed.

(Continued on next page)

\footnotetext{
* Correspondence: roque.rodriguez@usc.es

'Sustainable Forest Management Unit (UXFS), Department of Plant Production and Engineering Projects, Universidade de Santiago de Compostela (USC), Rúa Benigno Ledo, Campus Terra, 27002 Lugo, Spain Full list of author information is available at the end of the article
} 
(Continued from previous page)

Conclusions: The nutrient assimilation index is higher in poplar grown under short rotation forestry management than in the other systems considered. Nutrient management of fast growing eucalyptus plantations could be improved by selecting efficient genotypes and limiting removal of wood. The values of the nutrient assimilation index are lower in the natural stands of native broadleaved species than in the other systems considered.

Keywords: Nutrient removal, Biomass crops, Poplar genotypes, Eucalyptus, Oak, Birch, Plantation sustainability

\section{Background}

The proposed measures of the climate conference held in Paris in 2015 include transformation of the current fossil fuel-based energy generation systems to sustainable and renewable energy (RE)-based systems by using so-called 'carbon-neutral' alternatives (Karvonen et al. 2017). Production of forest biomass is one such RE option and can be increased by the use of specific biomass crops or changes in forest management of plantations or native species (precommercial thinning for biomass or use of logging residues, among others). However, these alternatives have raised concerns because of potentially adverse effects on forest soil productivity (Thiffault et al. 2014). Forest sustainability criteria thus usually include factors such as soil fertility and nutrient removal (Haberl et al. 2010). Short-rotation forestry (SRF) systems, with rotations of 3-7 years, are not yet widely implemented as part of European land use (Don et al. 2012). In Spain, changes in incentives policies have returned SRF to the developmental or precommercial stage (san Miguel et al. 2015). Nevertheless, SRF plantations are expected to increase within a global scenario of bioeconomy and given the commitment of the European Union (EU) for $20 \%$ of energy to be produced from renewable sources by 2020 (EU 2009). Land classification is a basic step in forest management planning, to identify areas where logging residues could be removed (Thiffault et al. 2014), to predict SRF productivity (Pérez-Cruzado et al., 2014) and to identify the most appropriate species and genotypes for different areas (Sixto et al. 2015).

The landscape in large areas of northern Spain is characterised by forest land covered by semi-natural forests of deciduous trees, alternated with fast growing plantations of exotic trees (such as eucalyptus, managed in rotations of 10 to 18 years). Eucalyptus plantations are particularly important for pulp production in southwestern Europe, covering recently planted forest land and, to a lesser extent, agricultural land (Díaz-Balteiro and Rodríguez 2006; Madeira and Araújo 2015). Pedunculate oak is a major natural forest species in Europe, covering the northern area of Spain in Galicia and the Cantabrian range (Gómez-García et al. 2015). Downy birch is one of the two commercially important Betula species grown in Europe (Hynynen et al. 2009); in northern Spain it acts as a pioneer species in humid or wet areas, with fast but unsteady growth.
Management of natural deciduous forest entails the removal of comparatively low amounts of biomass and the application of longer rotations than in conventional fast-growing plantations (Gómez-García et al. 2016). Provided that conventional patterns of extraction of woody components are applied, there are no major concerns about the nutrient sustainability of these native, extensively managed deciduous forests (Ranger and Turpault 1999). However, this is not true for intensively exploited forest plantations or SRF, and one of the key aims of nutrient sustainability in such cases is to obtain an overall balance by assessing the nutrient fluxes that occur throughout the rotation, including the amounts removed during clearfelling (Laclau et al. 2010; Vanbeveren et al., 2016). Estimation of the amounts of nutrients removed requires knowledge of the amounts of biomass in each compartment (stumps, wood, bark, branches of different sizes and leaves) and the nutrient concentrations in these components (Viera et al. 2016). However, the main drawback of this approach is that nutrient concentrations in biomass compartments vary depending on plantation age, site and even tree density (Judd et al. 1996; Rytter 2002; Leite et al. 2011), although the concentrations stabilize in mature stands (Augusto et al. 2008). Nutrient exportation via biomass removal is just one of the processes in the whole cycle. Nutrient losses can also occur through erosion or leaching, and the overall nutrient budgets are known to be site-specific (Ranger and Turpault 1999).

Short rotation forestry (3-7 years) management of poplar and eucalypt genotypes has been studied as a way of producing biomass to enhance the bio-economy in Spain (González-García et al. 2013; Oliveira et al. 2017). Most of the poplar genotypes used correspond to the Populus $\times$ euramericana and Populus $\times$ interamericana parental groups, the latter of which is considered less site demanding (Soulères 1984). As a rule, the harvest of SRF considers the whole tree, and thus only the leaves of perennial species are harvested (Sochacki et al. 2013). Debarking is not an option for the small diameter shoots harvested in this case, as the usual method of harvesting entails chipping all the aboveground components (san Miguel et al. 2015; Eufrade et al. 2016). For pulp plantations, which are usually felled in cycles longer than 10 years in Spain, intensive management may lead to negative budgets (Merino et al. 2005). Several management options aiming 
at minimizing negative nutrient budgets in forest plantations have been proposed: removal of only the wood component, leaving the bark in place; management of logging residues to enable reincorporation of the nutrients into the soil (Achat et al. 2015); and modification of soil preparation techniques (Merino et al. 2003; Viera et al. 2016). Other possible management adaptations include re-definition of rotation length (Viera et al. 2015) and the use of genetically improved materials with enhanced nutrient assimilation index (NAI), defined as the amount of biomass produced per unit of nutrient (Sochacki et al. 2013).

Carbon concentrations can also be used to predict the potential sequestration of this element in forest biomass and associated products. This application is receiving currently great interest, as the estimation of forest carbon stocks is in the core of the international agreements for greenhouse gasses emission reductions (Angelsen et al. 2012). Although the most common approach is to use a fixed $\mathrm{C}$ concentration in biomass components per species (Pérez-Cruzado et al. 2011), a better understanding of the sources of variation in $\mathrm{C}$ concentrations is required. The interest in reducing the uncertainty in $\mathrm{C}$ stock estimation in forest systems is twofold: the greater value of those initiatives where $\mathrm{C}$ emissions reductions are estimated with lesser uncertainty (Angelsen et al. 2012), and the avoidance of systematic errors causing overestimation.

The main objective of this study was to evaluate the sources of variation in the concentrations of carbon and nutrients in biomass compartments usually removed during harvesting operations, covering a range of species and management conditions: semi-natural forests, eucalypt pulp plantations and poplar and eucalypts grown as SRF. We also aimed to explore differences among species and genotypes and the effect of age and tree size on nutrient concentrations in the different compartments. We hypothesized that several genotypes of poplar and eucalypts will provide biomass at a relatively low nutrient cost.

\section{Methods}

\section{Species and plots sampled}

A network of 60 plots covering five species (Betula pubescens, Quercus robur, Eucalyptus globulus, Eucalyptus nitens and Populus spp.) was established for evaluation of biomass and nutrient concentrations in Galicia (NW Spain). The native species were sampled in plots established in semi-natural stands managed on intermediate to long rotations, and the range of ages and tree sizes was thus very broad (Table 1 ). The stands of both eucalypt species were managed as conventional forest plantations for pulp production (average initial density 1125 trees $\cdot \mathrm{ha}^{-1}$ ). These plots were established as a chronosequence, with ages ranging from 1 to 17 years. In the case of poplar, the four plots were managed as short rotation crops, with rotation of 4-
7 years and initial stocking of 6700 cuttings $\mathrm{ha}^{-1}$. The total sample size was 430 trees, including a very variable number of each species, ranging from the $12 \mathrm{E}$. nitens trees sampled to 150 or 154 in the case of stools of Populus SRF (Table 1). The plant material used in the study was a local provenance in the case of each of the two autochthonous species and different number of genotypes of the fast growing species (poplar and eucalypts). These were three for E. globulus (commercial seeds, Anselmo and Odiel) and one E. nitens (McAlister). The eucalypts were selected from blue gum stands or from crosses of F0 clones developed for drought resistance, rooting ability, growth, pest resistance and pulp yield, and the plants were raised from mini cuttings (López et al. 2010). Among the 8 poplar genotypes, three corresponded to $P . \times$ euramericana (I-214, AF2 and AF6), one to $P . \times$ interamericana $\times P$. nigra (Monviso), three of $P . \times$ interamericana (Unal, Beaupre and Raspalje) and one for $P$. trichocarpa (Trichobel).

The four poplar SRF plots are located in a flat area in fluvial terraces of tertiary materials consisting of gravels of quartz, sandstone and slates bound in a matrix of clay and sand. The soil texture is sandy clay loam, with average percentages of sand (56\%), silt (21.4\%) and clay (22.6\%). Average soil depth is $80 \mathrm{~cm}$ and the soil can be classified as Regosol (IUSS Working Group WRB 2015). The soil is acidic, with high saturation of $\mathrm{Al}$ in the exchange complex, and a very low availability of $P$. The chemical parameters of the first $40 \mathrm{~cm}$ soil layer are presented in Table 2 . As for the other species studied, the plots were mainly established in forest land not previously used for agriculture and the soils were mainly classified as Regosols and Umbrisols, with a relevant proportion of Cambisols for the native species and a minor presence of leptosols in the eucalypt plantations, according to the FAO classification (IUSS Working Group WRB 2015). The combined information on chemical soil properties of the upper $40 \mathrm{~cm}$ soil layer, without separation of the samples of each species, is shown in Table 2.

The climate in the study region is characterized by mild temperatures (annual average temperature $9{ }^{\circ} \mathrm{C}-14{ }^{\circ} \mathrm{C}$ ) and a slight water deficit in summer (average annual rainfall, $1000-2000 \mathrm{~mm}$; average annual evapotranspiration, $700-850 \mathrm{~mm}$; water deficit, $150-40 \mathrm{~mm}$ ). Within this general framework, birch stands are frequent in the moister areas, oak stands are widespread but occur more frequently in hilly areas, whereas eucalypt plantations mainly cover coastal areas with mild temperatures. The annual rainfall is lower and water deficit is higher in the basins where poplar is frequently planted.

Management of each stand involves a specific pattern of harvesting biomass components, as well as management of logging residues and reapplication of nutrients through fertilization. Such management can be considered relatively homogeneous for each species or group of species (Table 3). 
Table 1 Descriptive statistics (mean and standard deviations, range of diameter and age) of the sampled trees $(n=430)$

\begin{tabular}{|c|c|c|c|c|c|c|}
\hline & Quercus robur & Betula pubescens & $\begin{array}{l}\text { Eucalyptus } \\
\text { globulus }\end{array}$ & Eucalyptus nitens & $\begin{array}{l}\text { Populus euramericana } \\
\text { and } P . \times \text { interamericana } \times \\
P . \text { nigra }\end{array}$ & $\begin{array}{l}\text { Populus } \times \text { interamericana } \\
\text { and } P \text {. trichocarpa }\end{array}$ \\
\hline Management & $\begin{array}{l}\text { Semi-natural } \\
\text { forest }\end{array}$ & $\begin{array}{l}\text { Semi-natural } \\
\text { forest }\end{array}$ & Forest plantation & Forest plantation & SRF & SRF \\
\hline Plots & 6 & 9 & 25 & 12 & 4 & 4 \\
\hline Tree number & 19 & 34 & 61 & 12 & 150 & 154 \\
\hline Diameter (cm) & 18.1 (6.1) 5.8-37.7 & 13.9 (5.9) 7.7-27.1 & 15.3 (8.0) 5.8-37.7 & 20.8 (5.9) 13.3-34.1 & $4.4(1.5)$ 1.9-9.1 & 5.0 (1.5) 2.0-8.6 \\
\hline Age (years) & 74 (20.2) 53-108 & 33 (11.0) 22-64 & $8.6(3.0) 1-17$ & 10.8 (1.4) 9-13 & $5.6(1.5) 4-7$ & $5.3(1.5) 4-7$ \\
\hline $\begin{array}{l}\text { Clones/ } \\
\text { genotypes }\end{array}$ & 1 & 1 & 3 & 1 & 4 & 4 \\
\hline
\end{tabular}

The diameter refers to breast height diameter, except for the poplars, for which the basal diameter is provided

The site index values for E. globulus ranged from 7 to 25 , with an average of $16 \mathrm{~m}$ for dominant height (reference age 7 years). The SI was calculated for each plot with the EucaTool ${ }^{\circledR}$ application (Rojo-Alboreca et al. 2015). The average site index of the oak plots was $15.5 \mathrm{~m}$ (reference age $t_{r}=60$ years), whereas the mean site index of birch was $11.6 \mathrm{~m}\left(t_{r}=20\right)$, both of which are intermediate-high values for the region (Diéguez-Aranda et al. 2009). This variable was not included as a source of variation in the analysis because it could not be estimated for the very young poplar crops.

\section{Tree sampling}

The tree sampling differed slightly for the different groups of species. For birch, oak and eucalypts, three trees were selected per plot, to provide a good representation of the diameter range. Each plot corresponded to a specific genotype, and the sampling was carried out in summer. For poplar, the four plots under study each included 8 genotypes, and 10 (only 9 available in some cases) stools were thus chosen per plot and genotype, also with the aim of fully representing the diameter range. Bare poplar trees (without leaves) were sampled in winter, the usual time for harvesting SRF.

In each harvested tree, we separated aboveground biomass into the following components: wood and bark (portion between ground level and tree apex), split into one $\mathrm{m}$-long logs; thick branches ( 2.5 to $7 \mathrm{~cm}$ over bark); thin branches ( 0.6 to $2.5 \mathrm{~cm}$ over bark); twigs $(<0.6 \mathrm{~cm}$ over bark); and leaves including petiole. The components considered for oak and birch had to consider branches of more than $7 \mathrm{~cm}$, along with minor differences in the thin-end diameters, as is detailed in Gómez-García et al. (2015). The fresh weight of each tree component was measured and samples were obtained to determine the dry weight, percentage of bark in the stem and nutrient contents and thus enable application of the complete weighting procedure (Pérez-Cruzado and Rodríguez-Soalleiro 2011). Wood with bark was sampled by removal of three disks along the stem, considering relative heights of $0.15,0.33$ and 0.75 . The disks were processed to remove and measure the bark component and thus the three samples were pooled together. Branches were sampled at random along the canopy, with at least one sample taken from each $1 \mathrm{~m} \mathrm{log}$, by applying a sampling intensity of $15 \%-20 \%$ (maximum, $20 \mathrm{~kg}$ ) of the

Table 2 Descriptive statistics of the chemical parameters of the soils (mean value and standard deviations)

\begin{tabular}{llll}
\hline & Oak and birch $(n=15)$ & Eucalyptus $(n=15)$ & Populus $(n=15)$ \\
\hline Soil types & Cambisols, Umbrisols, Regosols & Leptosols, Regosols, Umbrisols, Cambisols & Regosols \\
$\mathrm{pH}_{\mathrm{KCl}}$ & $3.9(0.2)$ & $3.8(0.4)$ & 4.3 \\
$\mathrm{pH}_{\mathrm{H}_{2} \mathrm{O}}$ & $5.2(0.3)$ & $4.9(0.7)$ & 5.4 \\
$\mathrm{C}(\%)$ & $6.4(2.8)$ & $7.8(4.5)$ & 3.8 \\
$\mathrm{~N}(\%)$ & $0.5(0.2)$ & $0.5(0.4)$ & 0.3 \\
$\mathrm{P} \mathrm{Olsen}(\mathrm{ppm})$ & $6.5(2.8)$ & $6.8(3.2)$ & 12.4 \\
$\mathrm{Ca}\left(\mathrm{cmol}^{+} \cdot \mathrm{kg}^{-1}\right)$ & $0.46(0.13)$ & $0.44(0.30)$ & 1.41 \\
$\mathrm{Mg}\left(\mathrm{cmol}^{+} \cdot \mathrm{kg}^{-1}\right)$ & $0.40(0.10)$ & $0.70(0.40)$ & 0.52 \\
$\mathrm{~K}\left(\mathrm{cmol}^{+} \cdot \mathrm{kg}^{-1}\right)$ & $0.32(0.16)$ & $0.15(0.05)$ & 0.49 \\
$\mathrm{CEC}\left(\mathrm{cmol}^{+} \cdot \mathrm{kg}^{-1}\right)$ & $2.70(0.90)$ & $2.11(1.30)$ & 4.8 \\
$\mathrm{Al} \mathrm{saturation} \mathrm{( \% )}$ & $55(15)$ & $61(20)$ & 46.7
\end{tabular}

CEC refers to cation exchange capacity 
Table 3 Management of the plots of the species considered

\begin{tabular}{|c|c|c|c|}
\hline & Oak and birch & Eucalyptus & Populus \\
\hline Type of stand & Semi-natural forest & First rotation to be coppiced & First rotation to be coppiced \\
\hline Previous use & Deciduous forest & Eucalypt plantation or shrub cover & Pasture/agricultural land \\
\hline Components removed & $\begin{array}{l}\text { Wood and bark, thinning + } \\
\text { regeneration felling every } \\
40-90 \text { years }\end{array}$ & Wood and bark, rotation of 10 to 18 years & $\begin{array}{l}\text { Wood, bark and branches, } \\
\text { rotation of } 4-7 \text { years }\end{array}$ \\
\hline Fertilization at planting & None & $\begin{array}{l}40 \mathrm{~g} \text { plant of slow release coated fertilizer } \\
9 / 23 / 24+4 \% \mathrm{MgO}+1 \% \mathrm{~B}\end{array}$ & $\begin{array}{l}\text { Legume shrub chopping } \\
\text { and incorporation to soil } \\
\text { through harrowing }\end{array}$ \\
\hline Maintenance fertilization & None & None & $\begin{array}{l}\text { Surface spread of 15:15:15 } \\
\left(240 \mathrm{~kg} \cdot \mathrm{ha}^{-1}\right)+\text { limestone } \\
\left(400 \mathrm{~kg} \cdot \mathrm{ha}^{-1}\right)\end{array}$ \\
\hline
\end{tabular}

total number of both sizes of branches in each tree. The same sampling intensity was applied to leaves, thus removing a subsample of the total amount. For poplar the subsampling did not include leaves, and all woody components and bark were pooled. The dead branches along the stem were pooled with the thin branches in the case of $E$. nitens.

The biomass components were dried at $65{ }^{\circ} \mathrm{C}$ until constant weight (i.e. for on average 3 days for the wood + bark component) and the material was ground to pass through a $0.5 \mathrm{~mm}$ sieve. The $\mathrm{C}$ concentration was determined by combustion in a LECO CNS-ICP analyser. Total $\mathrm{N}$ was determined in a LECO-2000 analyzer, and the plant material was digested with $\mathrm{HNO}_{3}$ in a microwave oven for determination of nutrient concentrations. After the samples were digested, the concentrations of $\mathrm{P}$, $\mathrm{K}, \mathrm{Ca}, \mathrm{Mg}, \mathrm{S}$ and micronutrients were measured by ICP-OES, with Barley 502-227 and EDTA included as certified reference materials. Twelve variables were measured for each sample. At the plot scale, biomass was calculated from measurements of each tree and application of genotype-specific equations of biomass estimation (Diéguez-Aranda et al. 2009; Oliveira et al. 2017).

\section{Data analysis}

The boosted regression tree (BRT) approach was used to explore the dependence between the five major explanatory variables (biomass component, species, genetics, age and tree diameter) and nutrient concentrations. The final BRT model is an additive regression model in which individual terms are simple trees fitted in a stepwise process. We followed the procedure, code and the tutorial developed by Elith et al. (2008). Tree complexity was established at an intermediate value $(t c=4)$, relative to the sample size (total number of observations, 1059), and the proportion of data to be selected at each step was set at 0.5 (bag fraction). The learning rate was slow enough to always produce more than 1000 trees $(l r=0.01, n t>1000)$, and the response type considered was Gaussian. The previously mentioned code first determines the optimal $n t$ and then fits a final model to all the data (Elith et al. 2008).
For each variable of interest (12 concentrations), the deviance explained by the BRT model and the relative contributions of predictor variables were computed. The contributions are based on the number of times a variable is selected for splitting, weighted by the squared improvement to the model in each split, averaged over all trees (Friedman 2001). Some of the variables are nested to others (Genotype to Species) and so it would be difficult to explore the real contribution of each of them. In this case, we tried to derive the contribution of each variable by running a BRT analysis removing the other. The models were fitted using the gbm package 2.1.3 (Ridgeway 2017) implemented in $\mathrm{R}$ (version 3.4.2, R Core Team 2017).

Conventional statistical techniques were also used for each group of exploratory variables. Subsets of data were produced, as the effects (Species, Genetics, Age or size) should be adequately separated in the data. Diameter and age would be highly correlated and the relative contribution of each variable in the BRT model would be related to the correlation between variables. The woody component of poplar was assumed to be wood, to enable comparisons among the six species. The effect of genetics was only able to be studied for those species in which several genotypes were sampled (poplar and E. globulus). Likewise, the effect of age was only able to be studied for those species for which a wide range of ages were sampled in a chronosequence (E. globulus, B. pubescens, Q. robur). The size effect was only examined in poplar, in which the effect could be separated from the age effect. We applied one-way analysis of variance or covariance (ANCOVA), considering age or diameter as covariables when necessary. The analysis was implemented in $\mathrm{R}$ by using the following model:

$$
y_{i}=\mu+G_{i}+t+\varepsilon_{j(i)}
$$

where $y_{i}$ is the variable analysed (concentrations of the macro and micronutrients), $\mu$ is the mean value, $t$ is stand age or the tree size, $G_{i}$ is the effect of each factor considered and $\varepsilon_{i}$ is the error term. 
The Tukey's studentized range test was used for pairwise comparisons. A logarithmic base model was used to model nutrient concentrations in biomass components when the ANCOVA indicated an age effect. The adjusted coefficient of determination $\left(R_{\mathrm{a}}{ }^{2}\right)$ and the mean square error (MSE) were used to evaluate the performance of the fitted models.

\section{Results}

\section{Exploring the contribution of each source of variation}

The BRT approach failed to provide a model for the (highly variable) concentrations of three of the micronutrients analysed (Fe, Mn and $\mathrm{Zn}$ ). The regression tree analysis showed that the biomass component was the most important explanatory variable, always explaining $\geq 33 \%$ of the variance. The biomass component was particularly important for explaining the variation in $\mathrm{N}, \mathrm{S}, \mathrm{P}$ and $\mathrm{C}$ concentrations, and it was less important for $\mathrm{Ca}, \mathrm{Mg}$ or $\mathrm{K}$ concentrations. The combination of the factors species and genotypes accounted for between $15.2 \%$ (K) and $39.6 \%$ (C) of the total deviation, and the genotype was much more important than the species itself. The factors age and diameter were comparatively more important for explaining $\mathrm{Ca}, \mathrm{K}, \mathrm{Mg}$ and $\mathrm{Cu}$ concentrations (Fig. 1).

Most nutrient concentrations varied widely depending on the component analysed, and followed one of three patterns. The pattern generally observed for several macronutrients $(\mathrm{N}, \mathrm{P}, \mathrm{K}, \mathrm{S})$ was leaves $>>$ twigs $>$ thin branches $\geq$ bark $>$ thick branches $\approx$ wood. A different pattern was observed for $\mathrm{Ca}$ and $\mathrm{Mg}$, exclusively in eucalypts: leaves $\approx$ bark $\approx$ twigs $>$ thin branches $>$ thick branches $\approx$ wood, indicating the relatively high content of both macronutrients in the bark component. A third pattern was observed for $\mathrm{C}$ : leaves $>$ twigs $>$ thin branches $\approx$ thick branches $\approx$ wood $>$ bark, indicating the relatively low content of $\mathrm{C}$ in the bark (with the exception of birch, as we will detail afterwards). The boxplots for macronutrients are shown in Fig. 2.

The general pattern observed for micronutrients (with slight variations) was leaves $>$ twigs $>$ thin branches $\approx$ thick branches $\approx$ bark $\approx \operatorname{wood}$ (Fig. 3 ).

\section{Effects of species and genotype for each component}

The contribution of the Species given by the BRT analysis is limited if the genotype is included as an explanatory variable. If the genotype was removed, the Species factor increased their contributions to $20 \%-37 \%$ of the variation, depending on the nutrient. Analysis of the effect of species on each biomass component revealed significant differences in most cases, particularly for the wood component (Table 4). The $\mathrm{C}$ concentrations in wood were highest in $E$. nitens and lowest in the poplars, probably because the poplar trees were relatively young. The difference between both species of eucalypts was noteworthy, as the $\mathrm{C}$ concentration in all components was lower in E. globulus than in E. nitens. The $\mathrm{C}$ concentrations in wood are higher than the ones in bark for all species, with the exception of birch. The concentrations of the other macronutrients (particularly $\mathrm{N}$ and P) were usually highest in poplar, intermediate in some birch and oak and lowest in the eucalyptus species. This general trend was not observed for $\mathrm{Ca}$, the concentrations of which were highest in birch and oak wood.

More specifically, the nutrient concentrations were slightly higher in $P . \times$ euramericana than in the $P . \times$

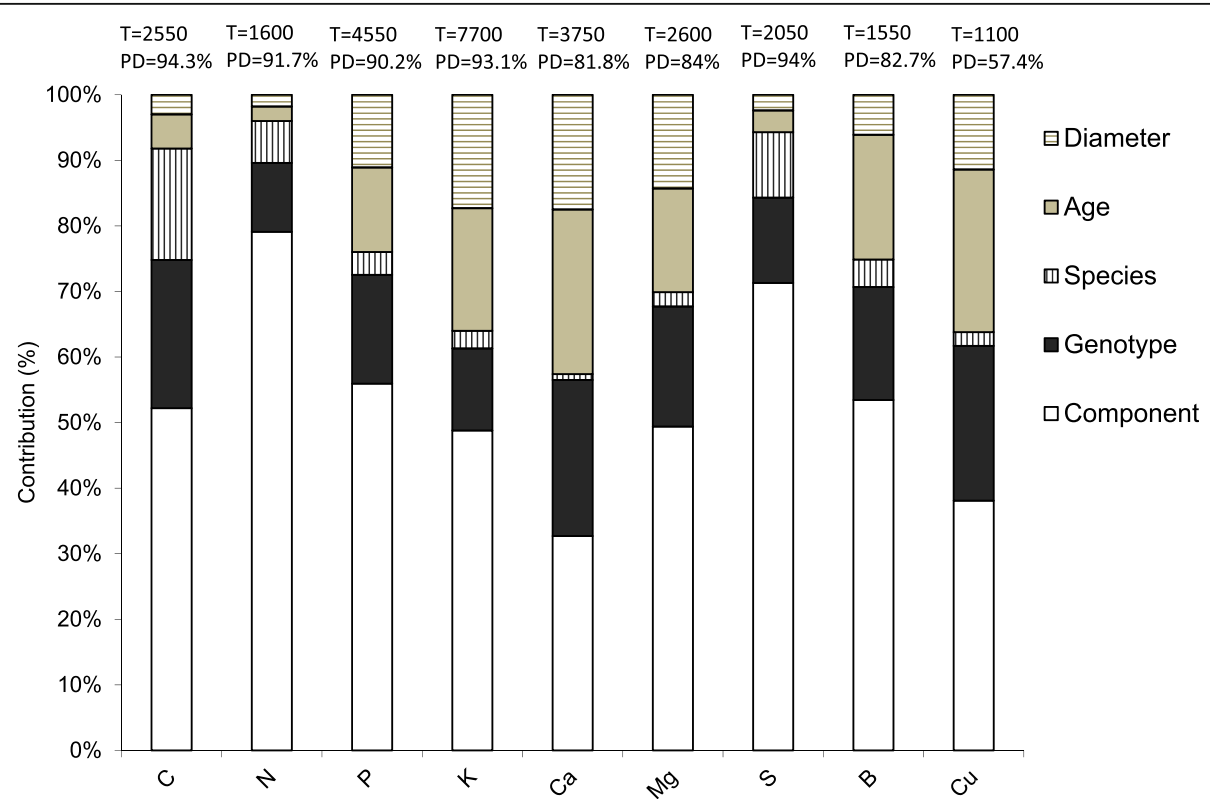

Fig. 1 Summary of relative contributions (\%) of predictor variables in the boosted regression tree model for each nutrient concentration analysed. $T$ is the number of regression trees and $P D$ the percentage of deviance explained 

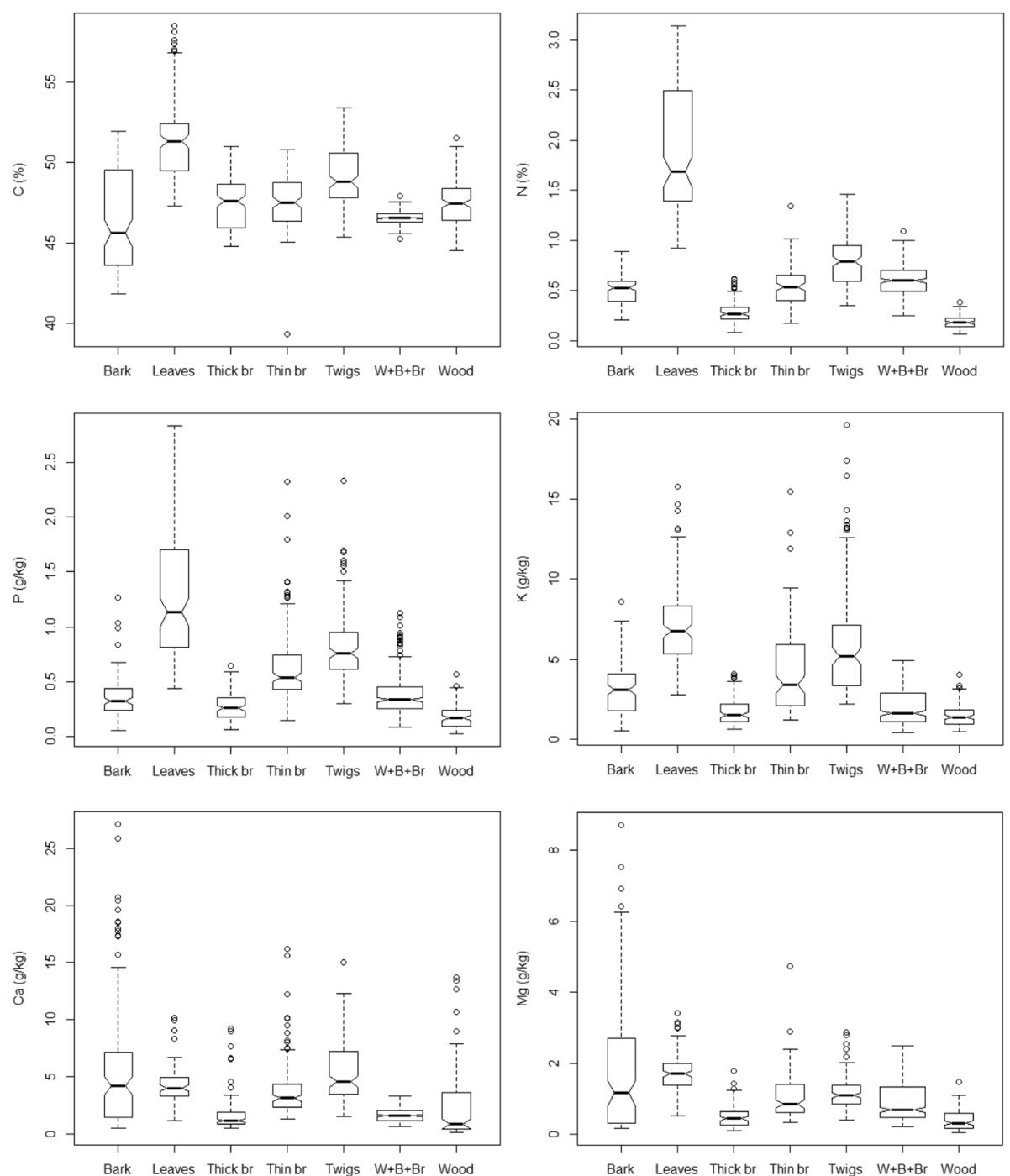

Fig. 2 Boxplots of macronutrients concentrations in each biomass component analysed. $W+B+B r$ is for poplar SRF (leafless aboveground components are considered together)

interamericana or $P$. trichocarpa genotypes (data not shown). Thus, the latter group needed immobilization of $22 \%$ less N, 25\% less P, 23\% less K, 9\% less Ca and 26\% less $\mathrm{Mg}$ than $P . \times$ euramericana in the woody components to produce a ton of wood. A similar result was obtained for the comparison between E. globulus and E. nitens, and the latter required $44 \%$ less N, 36\% less P, 37\% less K, $42 \%$ less $\mathrm{Ca}$ and 29\% less Mg than E. globulus per unit of wood produced. Indeed, E. nitens contains the lowest concentrations of these nutrients of the five species studied. The ratio of $\mathrm{Ca}: \mathrm{Mg}$ concentrations in wood was very different in the three groups of species: 6.5 for oak and birch, 2.8 for poplar and only 1.9 for eucalypts.

The foliar concentrations of the following nutrients were higher in both deciduous species than in the eucalypts: $\mathrm{N}$ (+ 69\%), P (+ 97\%), K (+ 53\%), Mg (+ 32\%), S (+ 81\%) and B
(+ 46\%) (Table 4). The Ca concentrations did not differ significantly between species. The foliar $\mathrm{C}$ concentrations were higher in the eucalypts, particularly $E$. nitens, than in the other species. Comparison with poplar was not possible, as leaves were not collected from this species. Considering the bark, the mean concentrations of the alkaline elements were higher in both eucalypt species than in the birch and oak. E. nitens shows particularly high $\mathrm{Ca}$ concentrations in bark. The $\mathrm{K}, \mathrm{Ca}$ and $\mathrm{Mg}$ concentrations in the bark of birch and oak were similar to those in wood. The nutrient concentrations in the branches and twigs of eucalypts are generally similar to those in the autochthonous species.

The genotype contributed notably to explain the variance of nutrient concentrations (Fig. 1). If the species factor is removed from the BRT, it is the genotype which 

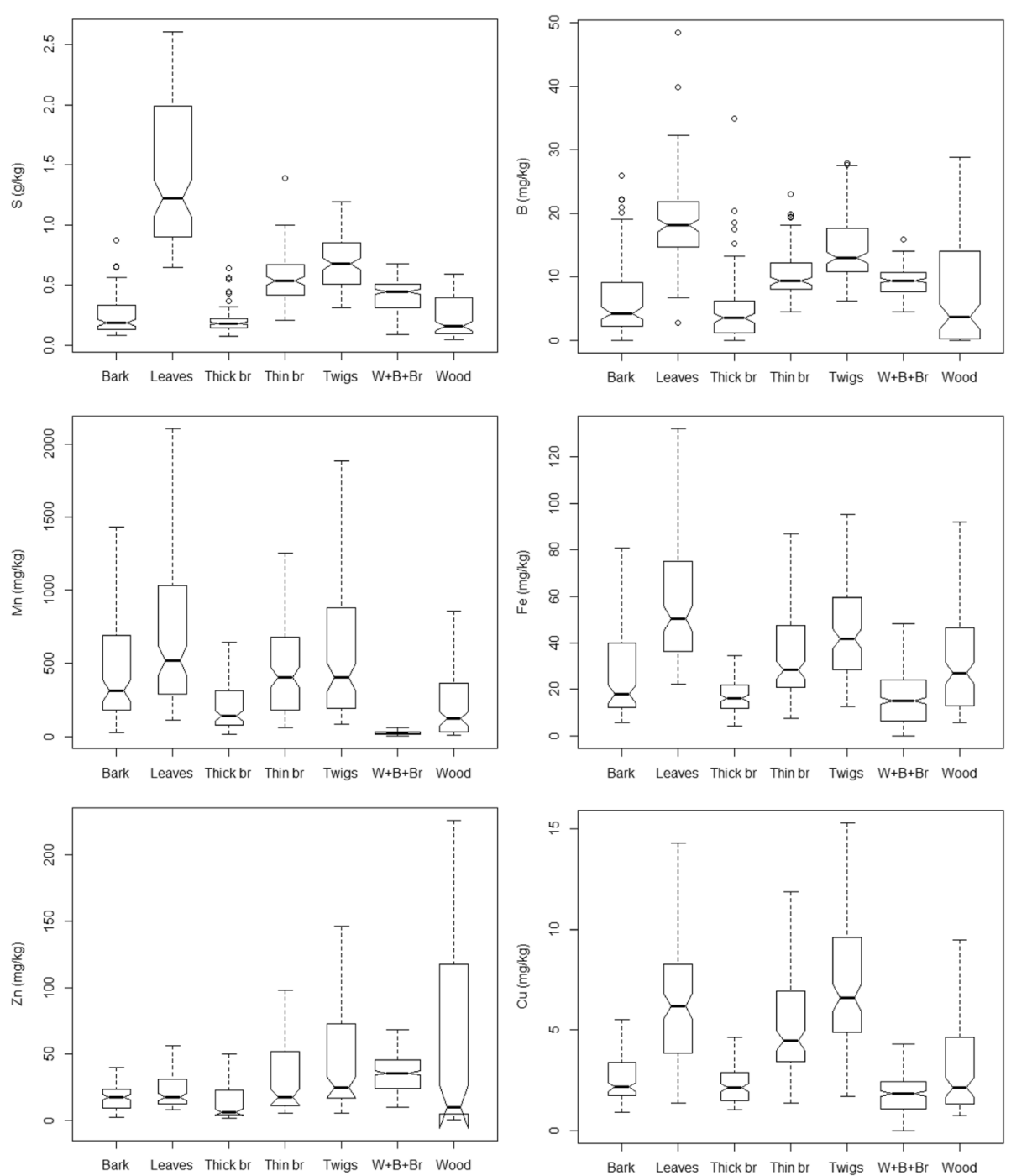

Fig. 3 Box plots of micronutrient concentrations in each biomass component analysed. $W+B+B r$ was used for poplar SRF (i.e. leafless aboveground components were considered together)

assumes its contribution (data not shown). The concentrations of $\mathrm{N}, \mathrm{K}, \mathrm{P}, \mathrm{Ca}, \mathrm{Mg}, \mathrm{S}$ and $\mathrm{B}$ in wood components differed in genotypes of the same species of $E$. globulus and of poplar. The concentrations were always lowest in the three E. globulus genotypes (Table 5). The concentrations were usually highest in four poplar genotypes (I-214, AF2, AF6 and Monviso), but with some overlap with a second group formed by Raspalje, Beaupré, Unal and Trichobel (particularly for $\mathrm{P}, \mathrm{Ca}$ and $\mathrm{S}$ ). This finding indicates the importance of choosing efficient genotypes that can immobilize low amounts of nutrients per unit biomass produced. Nutrient concentrations were much higher in commercial E. globulus seedlings than in the clones, especially for $\mathrm{P}, \mathrm{Ca}$ and $\mathrm{Mg}$. The F1 clone Odiel was much more efficient than Anselmo.

\section{Effects of age and size}

Tree age did not appear to affect the nutrient concentrations in leaves, bark or twigs. However, $\mathrm{P}$ and $\mathrm{K}$ concentrations in the branches of the eucalypts were negatively correlated with age. The concentrations of nutrients in the wood component were also usually negatively correlated with age. This was observed for $\mathrm{N}(\rho=-0.45, p=0.0003), \mathrm{P} \quad(\rho=$ $-0.50, p<0.0001), \mathrm{K}(\rho=-0.47, p=0.0002), \mathrm{Ca}(\rho=-$ $0.19, p=0.04), \mathrm{S}(\rho=-0.22, p=0.03)$ and $\mathrm{Cu}(\rho=-0.31$, $p=0.001)$ in the eucalypts and for $\mathrm{P}(\rho=-0.31, p=$ $0.015), \mathrm{K}(\rho=-0.25, p=0.03), \mathrm{Ca}(\rho=-0.25, p=0.03)$, $\operatorname{Mg}(\rho=-0.14, p=0.04), \mathrm{S}(\rho=-0.42, p=0.001), \mathrm{Cu}(\rho$ $=-0.34, p=0.005)$ and $\mathrm{B}(\rho=-0.36, p=0.008)$ in the deciduous species. The nutrients affected by this trend were thus slightly different in both groups of species, as was the intensity of the relationship. It was not possible to fit an 


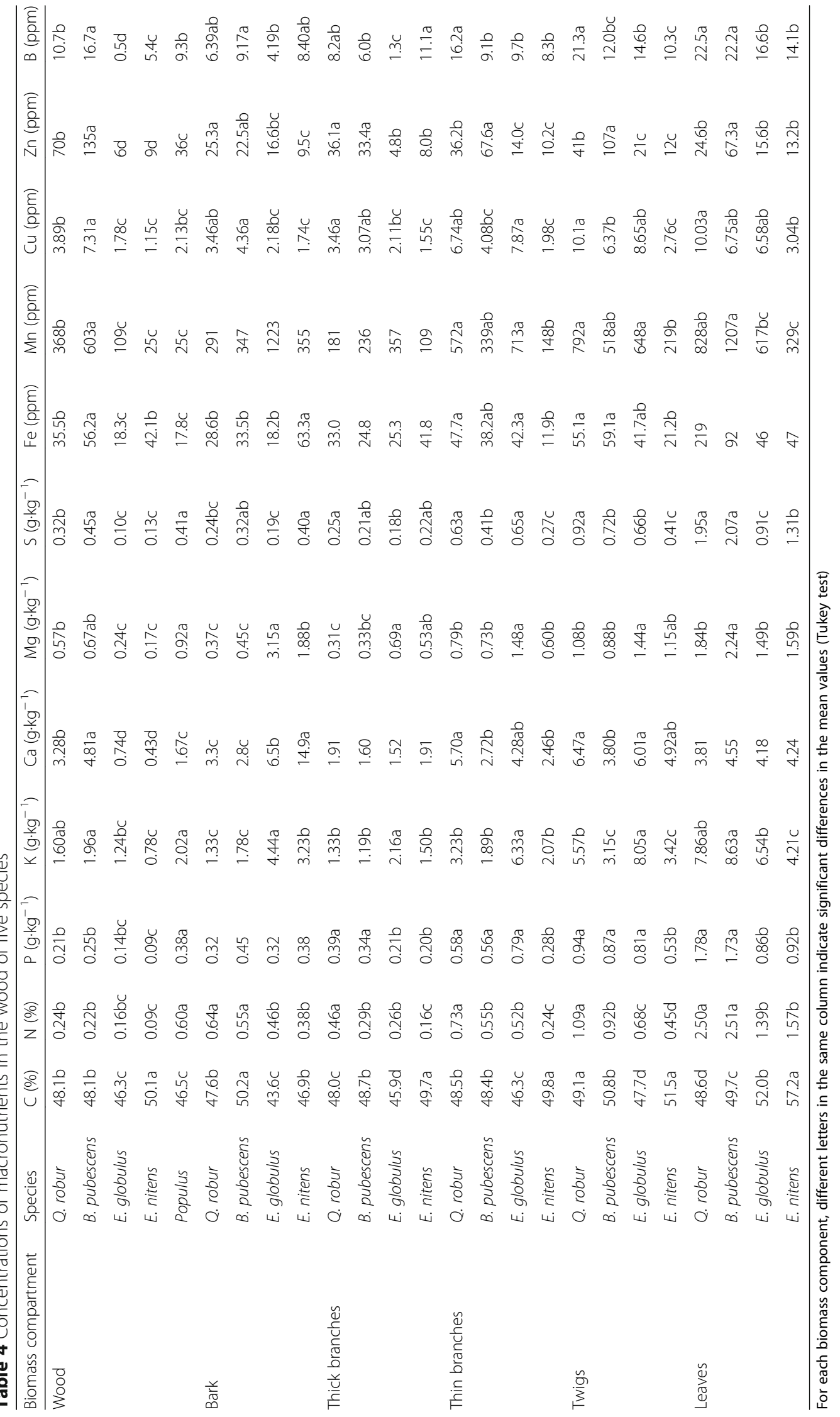


Table 5 Concentrations of macronutrients in wood of 11 genotypes corresponding of two species of Populus and one species of Eucalyptus

\begin{tabular}{|c|c|c|c|c|c|c|}
\hline N (\%) & $\mathrm{P}\left(\mathrm{g} \cdot \mathrm{kg}^{-1}\right)$ & $\mathrm{K}\left(\mathrm{g} \cdot \mathrm{kg}^{-1}\right)$ & $\mathrm{Ca}\left(\mathrm{g} \cdot \mathrm{kg}^{-1}\right)$ & $\mathrm{Mg}\left(\mathrm{g} \cdot \mathrm{kg}^{-1}\right)$ & $\mathrm{S}\left(\mathrm{g} \cdot \mathrm{kg}^{-1}\right)$ & $B\left(\mathrm{mg}^{\prime} \mathrm{kg}^{-1}\right)$ \\
\hline 0.78a AF6 & 0.57a AF6 & 2.53a AF6 & 1.99a I-214 & 1.29a I-214 & 0.50a UNAL & 10.9a AF6 \\
\hline 0.66b MON & $0.46 a b$ l-214 & 2.28ab I-214 & 1.81a MON & 1.12ab AF2 & $0.47 a b$ l-214 & 10.5a AF2 \\
\hline $0.64 \mathrm{bc}$ l-214 & $0.40 \mathrm{bc} \mathrm{MON}$ & 2.22abc MON & 1.68a AF2 & 0.99bc AF6 & 0.43abc AF6 & 10.4a MON \\
\hline $0.63 \mathrm{bc}$ AF2 & $0.36 \mathrm{bc} B E A$ & 2.17abc AF2 & 1.63a RAS & $0.91 \mathrm{bc} \mathrm{MON}$ & $0.43 a b c$ RAS & 10.1ab I-214 \\
\hline $0.57 \mathrm{bcd}$ BEA & $0.35 \mathrm{bc}$ RAS & 1.96abcd TRI & 1.60a BEA & $0.83 b c$ TRI & 0.42abc BEA & 8.6bc TRI \\
\hline $0.56 \mathrm{cde}$ RAS & $0.34 \mathrm{bc}$ TRI & 1.91abcd BEA & 1.58a TRI & $0.83 \mathrm{bc} B E A$ & $0.42 \mathrm{abc} \mathrm{MON}$ & 8.0c UNAL \\
\hline 0.52de UNAL & $0.32 \mathrm{bcd}$ AF2 & $1.68 \mathrm{bcd}$ RAS & 1.58a AF6 & $0.79 \mathrm{bc}$ RAS & $0.35 b c$ TRI & 7.7c RAS \\
\hline 0.46e TRI & $0.27 \mathrm{cde}$ UNAL & $1.45 \mathrm{~cd}$ UNAL & 1.57a UNAL & $0.67 \mathrm{~cd}$ UNAL & $0.34 \mathrm{C} A F 2$ & 7.6c BEA \\
\hline $0.18 f$ SEED & 0.20def SEED & $1.32 d$ ANS & 1.47a SEED & 0.32de SEED & $0.13 d$ SEED & 1.1d SEED \\
\hline $0.18 f$ ANS & $0.15 \mathrm{ef}$ ANS & $1.24 d \mathrm{ODI}$ & 0.50b ANS & 0.20 e ANS & $0.10 \mathrm{~d}$ ANS & $0.3 \mathrm{~d}$ ANS \\
\hline $0.14 \mathrm{fODI}$ & $0.10 f \mathrm{ODI}$ & 1.16d SEED & $0.44 \mathrm{~b}$ ODI & $0.20 \mathrm{e}$ ODI & 0.08d ODI & $0.2 \mathrm{~d}$ ODI \\
\hline
\end{tabular}

Different letters in the same column indicate significant differences in the mean values between genotypes (Tukey test). Only the nutrients showing significant differences are shown

accurate regression model to the pattern due to the high level of intrinsic variation in the data, although the values for eucalypts appeared to stabilize from age 7-12 years onwards.

Although no age-related trends in $\mathrm{C}$ concentration were observed for any individual species, the pooled data for woody components (excluding bark, leaves and twigs) showed a pattern of increasing $\mathrm{C}$ concentrations with age. A parametric log-linear fit is provided for prediction purposes (Fig. 4). This finding indicates the need to consider an appropriate rate of $\mathrm{C}$ sequestration per unit of woody biomass depending on the type of management (SRF, plantation for small timber production or semi-natural forests), as an average value of $50 \%$ could only be sustained in long rotations.
As regards the effect of size of the tree, no correlations between nutrient concentrations and size were found in the case of poplar SRF data, which is the information able to clearly separate the effect of age from that of the tree dimension.

\section{Nutrient content at the end of the rotation}

In the poplar plantations, as all the genotypes were present in each plot, it was possible to compare the total amount of nutrients accumulated in the woody biomass (and thus likely to be removed from site by harvesting the biomass). Comparison of the two groups (Fig. 5) revealed that the Raspalje, Beaupré, Unal and Trichobel genotypes were able to absorb more nutrients from the same soil than the other genotypes ( $91 \%$ more $\mathrm{Ca}$ and

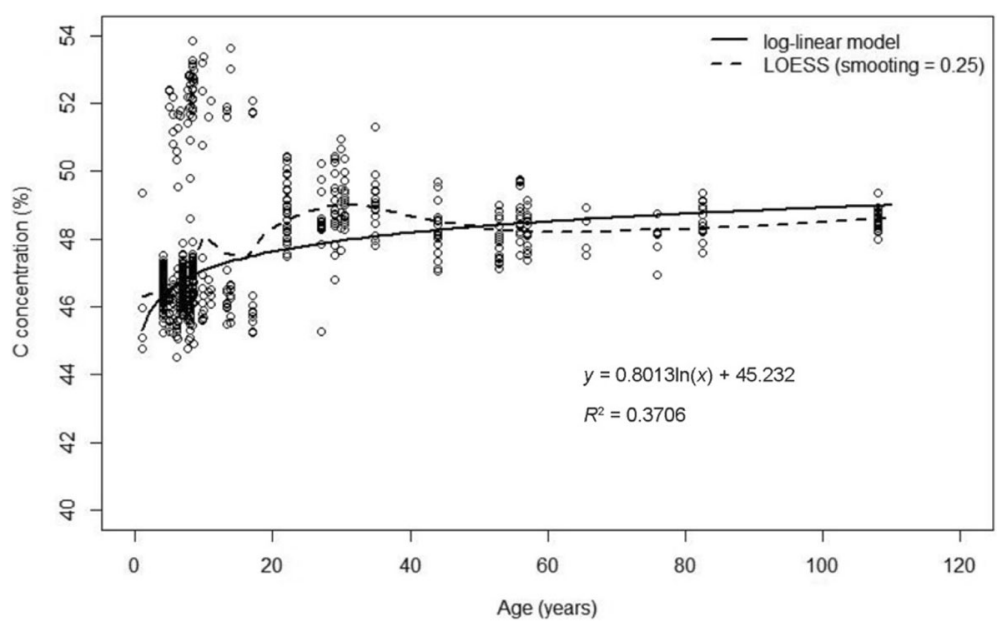

Fig. 4 Relationship between C concentrations for the wood and branches components (excluding bark) and age of the sampled trees. The dashed line corresponds to a local regression model (LOESS) fitted by using the loess function of R (R Core Team 2018) and a smoothing factor of 0.25 . All the species studied are pooled together 


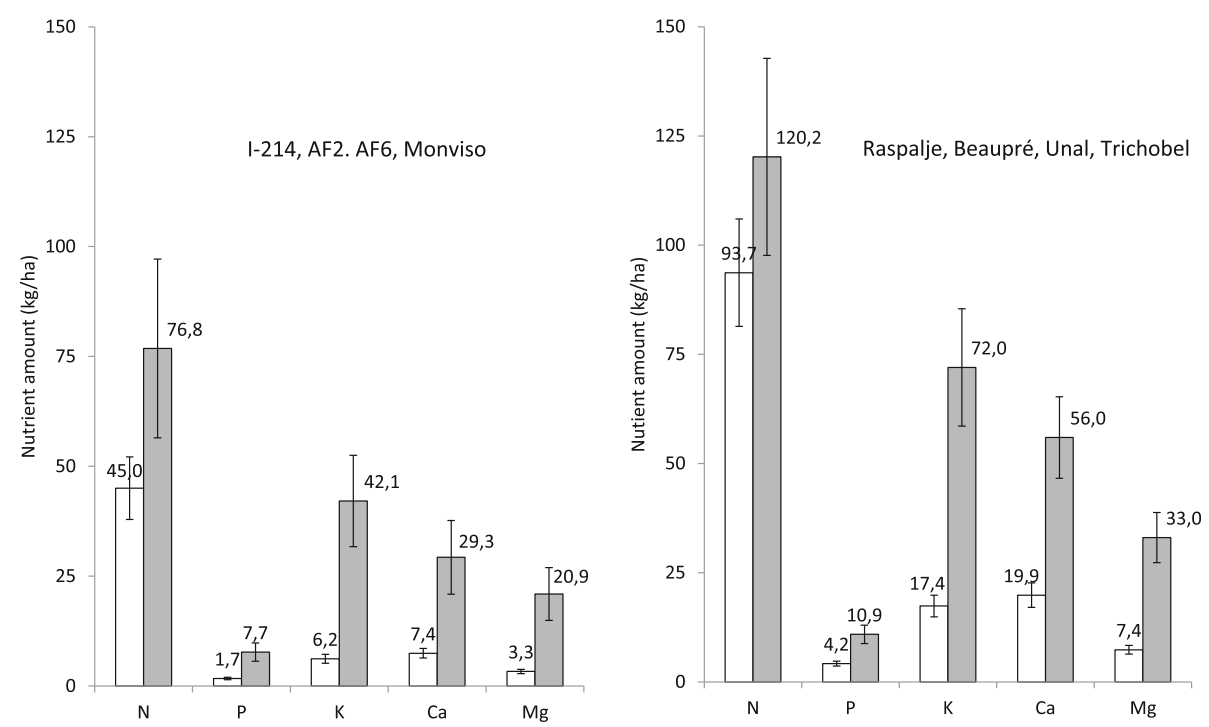

Fig. 5 Nutrient amounts in poplar SRF. White bars represent the 4-year-old plots and grey bars the 7-years-old plots

$71 \%$ more $\mathrm{K}$ for an age of 7 years). The most efficient group of poplar genotypes showed an average productiv-

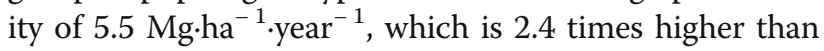
the average yield of the first group, which mainly comprises Euro-American crosses.

The $\mathrm{N}, \mathrm{P}, \mathrm{K}, \mathrm{Ca}$ and $\mathrm{Mg}$ contents in blue gum were calculated on a per ha basis for 4 age classes $(5-7,7-9$, $9-12$ and $12-18$ years). The number of plots available for each class ranged between 5 and 9. The results of Fig. 6 show the pattern of nutrient accumulation in aboveground biomass, which keeps increasing from age 9-12 to the 12-18 age class. The standard errors are lower for the 7-9 age class because 9 plots were available in this case. The relative contribution of wood increased with age $(50,48,51,34$ and $33 \%$ of $\mathrm{N}, \mathrm{P}, \mathrm{K}, \mathrm{Ca}$ and $\mathrm{Mg}$, respectively, is contained by the wood at rotation age), indicating that the increase in biomass largely compensated for the decreases in nutrient concentrations. The share of bark, particularly important for $\mathrm{Ca}$ and $\mathrm{Mg}$, also increased with age. The results for $E$. nitens after grouping all the plots together are also shown in Fig. 6.

The nutrient amounts in native broadleaved species were calculated as mean values after grouping the plots available for each species. The results of Fig. 7 show that the oak stands hold in the aboveground biomass large amounts of nutrients $(750,65,383,755$ and $117 \mathrm{~kg} \cdot \mathrm{ha}^{-1}$ of $\mathrm{N}, \mathrm{P}, \mathrm{K}, \mathrm{Ca}$ and $\mathrm{Mg}$, respectively), as a result of an average age of 74 years. The average age of birch plots is 33 years and the total content of nutrients is lower: 410, 40, 209, 371 and $64 \mathrm{~kg} \mathrm{ha}^{-1}$ of $\mathrm{N}, \mathrm{P}, \mathrm{K}, \mathrm{Ca}$ and $\mathrm{Mg}$, respectively. For both species, but more clearly in the case of oak, the proportion of thick branches is very relevant.

\section{Comparison of 4 scenarios of species and management} In order to facilitate discussion of the results, we considered four different combinations of species and management regimes:

1) PoplarSRF7. Poplar SRF with efficient poplar genotypes, rotation length of 7 years and removal of leafless aboveground biomass.

2) EucaSRF6. Eucalypt SRF considering all genotypes of E. globulus (represented by the plots in the age interval 5-7 years), rotation length of 6 years and removal of whole aboveground biomass.

3) Eucapulp15. Conventional forest plantation of Eucalypt blue gum (considering all genotypes) with rotation length of 15 years and removal of only the wood component.

4) Oakbirch. Combined Oak and birch management with rotation of 35 (birch) or 75 (oak) years, removal of wood, bark and thick branches to produce timber and firewood.

Three sets of variables were calculated: the nutrient assimilation index (NAI), as an indicator of efficiency in biomass production per unit nutrient; the mean annual nutrient removal (MANR) on a per ha basis; and the percentage of the available soil nutrients removed during harvesting (PASNR). For $\mathrm{N}$ removal, the percentage removed refers to the total $\mathrm{N}$ mineralization expected with a fixed annual rate of $1 \%$ of $\mathrm{N}$ mineralization. The values obtained are presented in Table 6.

The mean annual nutrient removals, except for $\mathrm{N}$, were higher for eucalypt SRF than for poplar. The lower values are associated with intermediate or long 


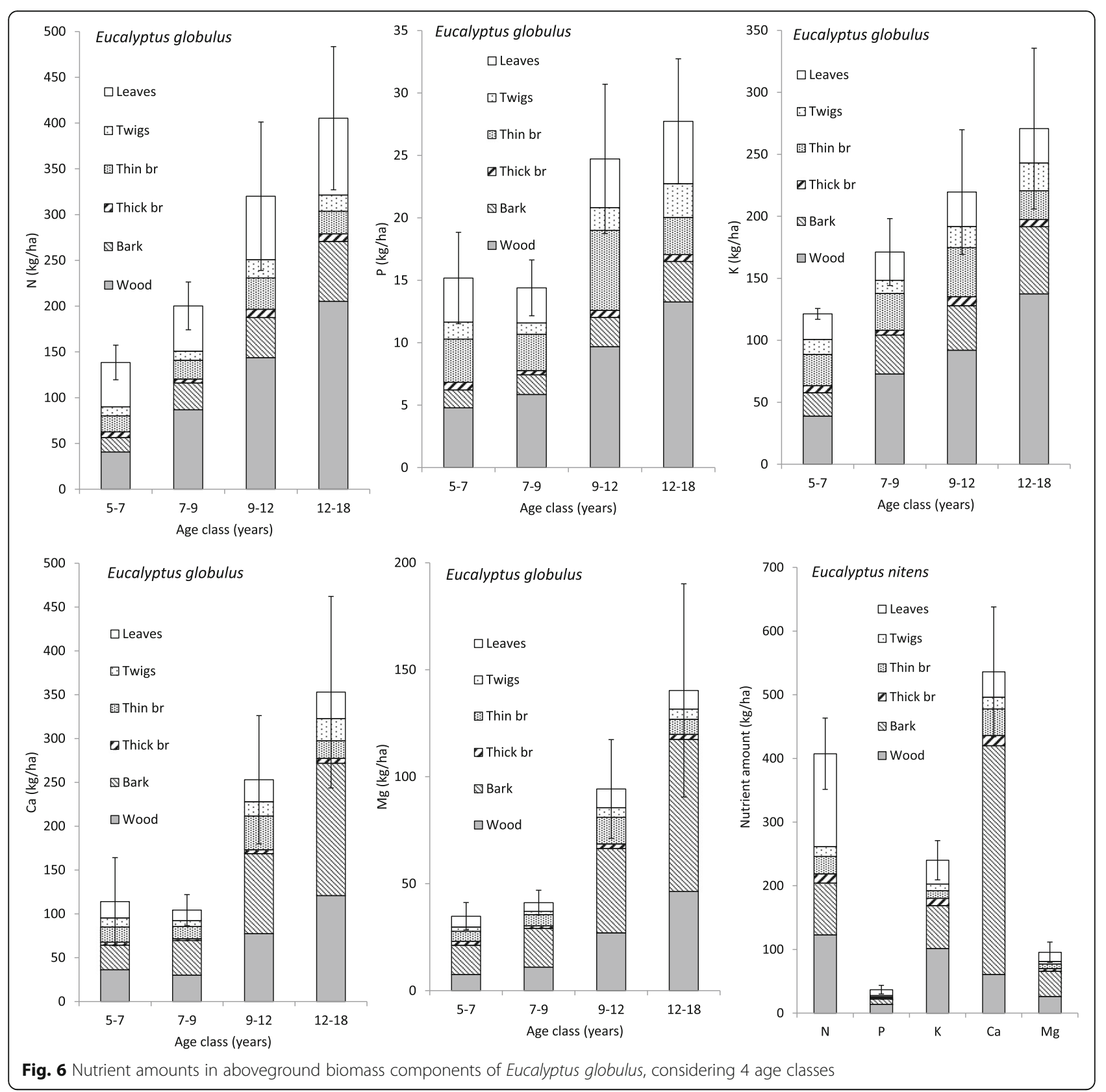

rotations in the regimes including both autochthonous species. The scenario of eucalypt managed for pulp show lower MANR values than the SRF of eucalypts and the NAI is 1.7 to 3.9 times higher than the values for poplar and eucalypts SRF. The MAI associated to this alternative is 16.3 under bark $\left(\mathrm{m}^{3} \cdot \mathrm{ha}^{-1} \cdot\right.$ year $\left.^{-1}\right)$, which using the values of specific wood consumption at that age (SWC, under bark $\left(\mathrm{m}^{3} \cdot \mathrm{Mg}_{\mathrm{ADP}}{ }^{-1}\right)$, i.e. the amount of debarked wood required to produce a ton of air dried pulp, Resquin et al. 2012), means a productivity of $5.51 \mathrm{Mg}_{\mathrm{ADP}} \cdot \mathrm{ha}^{-1} \cdot$ year $^{-1}$.

\section{Discussion}

The study findings emphasize the importance of the biomass component as the main factor explaining nutrient concentrations in a variety of combinations of broadleaved species and management regimes. This has been shown in several studies and for different species (Merino et al. 2005; Hernández et al. 2009; André et al. 2010) and is the main basis for proposing management scenarios in which the compartments to be removed are selected according to their impact in terms of nutrient removal per unit of biomass (Achat et al. 2015; Viera et al. 2015). 

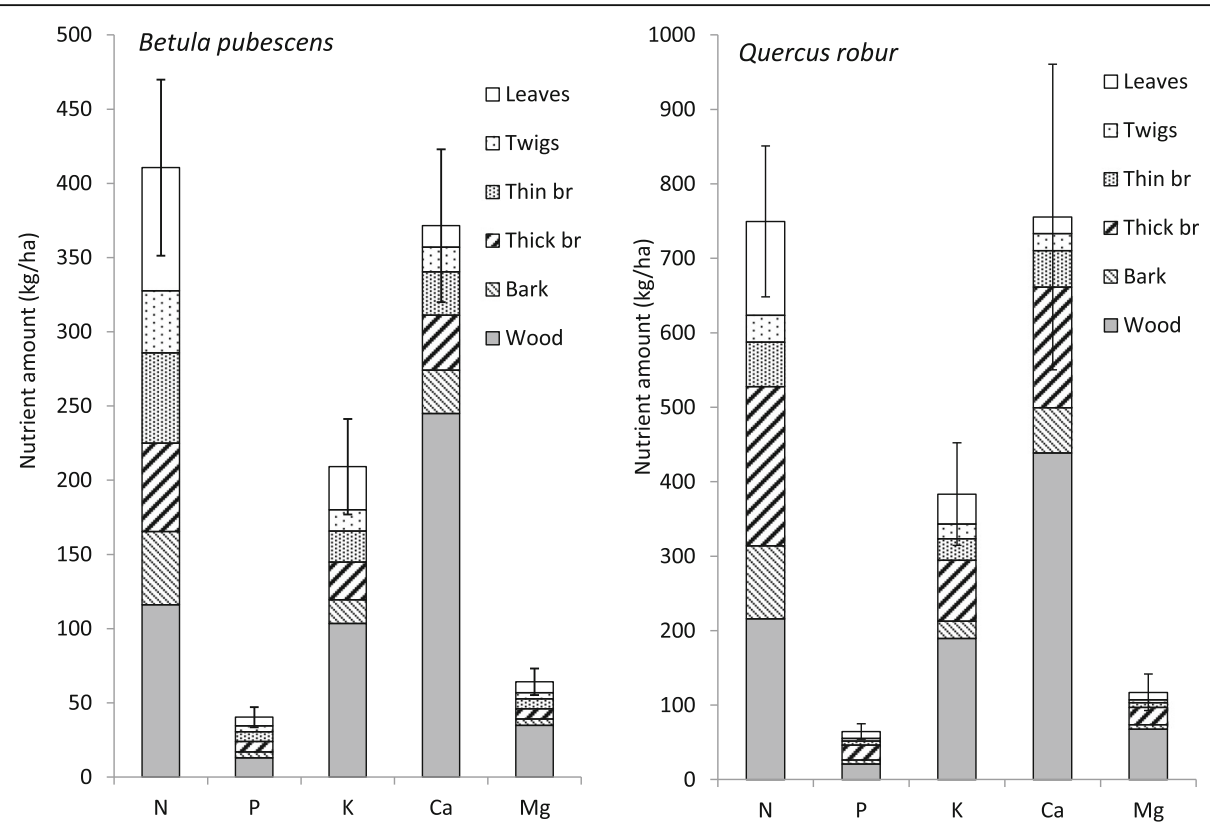

Fig. 7 Nutrient amounts in aboveground biomass components of Betula pubescens ( $n=9$ plots, left) and Quercus robur ( $n=6$ plots, right). Note the difference in the scale of the $y$-axis

The three types of management covered by the data represent specific systems with very different goals and products, and applied to different species and in specific locations. Comparative studies of several species growing on the same soils enable a better understanding of differences between species under similar conditions of nutrient availability (Hagen-Thorn et al. 2004). A limitation of this study is the lack of representation of all the species studied in the same sites. Even so, the dataset used shows that N, $\mathrm{P}, \mathrm{K}, \mathrm{Ca}$ and $\mathrm{Mg}$ concentrations in the woody components (except bark) are consistently higher in poplar, oak and birch than in eucalypts, and these macronutrients are greater than the ones reported for conifers in the same region (Merino et al. 2005). The variability among broadleaved species found in this study is consistent to the range of values reported in the literature (Wang et al. 1991; André et al. 2010; Gómez-García et al. 2016) although studies of the group of species considered here are scarce.

Calculation of carbon storage in biomass components should take into account tree age rather than average carbon concentration in biomass components. Longer rotations would be beneficial for carbon stock in biomass and products, as well as for bioenergy substitution (Pérez-Cruzado et al., 2012). The present findings also show that $\mathrm{C}$ concentrations did not reach $50 \%$ at older ages for any of the biomass components studied, except leaves. Previous studies have shown that average $\mathrm{C}$ concentrations are variable depending on species, tree size and/or age, and that the measured values in the trunk do not reach 50\% (Elias and Potvin 2003), but can be very closed to this figure for wood of a 14 years-old poplar plantations (Cruz Calleja, 2005). Overall, considering all the plots studied, the mean $\mathrm{C}$ concentration averaged with biomass was $46.5 \%$ for poplar SRF and $45.6 \%$ for wood and bark in eucalypts. Considering the whole aboveground biomass, these figures are $47.7 \%$ for eucalypt, 48.3\% for oak and $49.3 \%$ for birch. These results indicate the need to consider the variation in $\mathrm{C}$ concentration with age to simulate the amount of carbon captured and the limitations of the studies that used a fixed concentration (Giménez et al. 2013).

Table 6 Comparison of nutrient assimilation index (NAI), mean annual nutrient removal (MANR) and percent of available soil nutrients removed (PASNR) for five species-forest management combinations

\begin{tabular}{|c|c|c|c|c|c|c|c|c|c|c|c|c|c|c|c|c|}
\hline \multirow[t]{2}{*}{ Regime } & \multirow[t]{2}{*}{ Nº Plots } & \multicolumn{5}{|c|}{ MANR $\left(\mathrm{kg}^{\prime} \cdot \mathrm{ha}^{-1} \cdot\right.$ year $\left.^{-1}\right)$} & \multicolumn{5}{|c|}{ PASNR (\%) } & \multicolumn{5}{|c|}{ NAI $\left(\mathrm{Mg} \cdot \mathrm{kg}^{-1}\right)$ of nutrient } \\
\hline & & $\mathrm{N}$ & $P$ & K & $\mathrm{Ca}$ & $\mathrm{Mg}$ & $\mathrm{N}$ & $P$ & K & $\mathrm{Ca}$ & $\mathrm{Mg}$ & $\mathrm{N}$ & $\mathrm{P}$ & K & $\mathrm{Ca}$ & $\mathrm{Mg}$ \\
\hline PoplarSRF7 & 4 & 23.5 & 1 & 4.5 & 5 & 2.0 & 19 & 29 & 16 & 7 & 18 & 0.21 & 2.94 & 0.51 & 0.63 & 1.20 \\
\hline EucaSRF6 & 6 & 20.0 & 3 & 20 & 23 & 7.0 & 15 & 75 & 69 & 43 & 14 & 0.28 & 2.57 & 0.31 & 0.34 & 1.12 \\
\hline Eucapulp15 & 5 & 13.7 & 0.9 & 9.2 & 8 & 3.1 & 9 & 65 & 78 & 46 & 18 & 0.64 & 9.95 & 0.96 & 1.09 & 2.84 \\
\hline Oak-birch & 15 & 7.0 & 0.7 & 4.2 & 9.3 & 1.3 & 6 & 238 & 79 & 239 & 67 & 0.35 & 3.60 & 0.60 & 0.27 & 1.80 \\
\hline
\end{tabular}




\section{Short rotation forestry}

The SRF approach, which is applicable to both poplar and eucalypts, is devoted to the growth of small trees for biomass production in the short term. This management system provides little opportunity to remove but the whole aboveground biomass (Morhart et al. 2013), and it thus entails the extraction of large amount of nutrients every few years. In the case of the more efficient genotypes

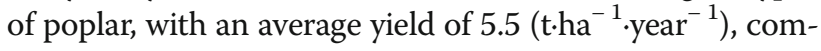
parison between the removal rates and the available amounts of nutrients in the soil show that $29 \%$ of the available $\mathrm{P}$ and $19 \%$ of the expected periodic $\mathrm{N}$ mineralization would be retained in the aboveground biomass after 7 years of growing poplar. Even if nutrient concentrations of poplar in this study are high compared to the other species studied, it is known that poplar has lower concentrations when compared to other biomass fuels, as Miscanthus (Jenkins et al. 1998), but also higher than willow (Tharakan et al. 2003).

The average yearly removal rates are lower (particularly for $\mathrm{P}$ and $\mathrm{Ca}$ ) than reported for more productive plantations (Adegbidi et al. 2001; Morhart et al. 2013). This is a result of lower nutrient concentrations, if compared to the combined wood + branches + bark component reported by other authors, particularly in the case of $\mathrm{Ca}$ and $\mathrm{P}$ (Jug et al. 1999; Tharakan et al. 2003) or to the proleptic branches reported by (Vanbeveren et al., 2016). The macronutrient concentrations found in poplar plantations for wood production in Spain were also higher than the ones of this study (Cruz Calleja, 2005). The concentrations of $\mathrm{Mg}$ and $\mathrm{N}$ are comparatively high in this study. The rates of removal found in 7-years old hybrid aspen plantations in Estonia are nevertheless comparatively lower than the ones found in this study (Tullus et al. 2009).

The poplar data reported in the present study, which correspond to only two age groups, enable separation of the effects of age and size. The results do not support the existence of different nutrient concentrations in trees of different sizes. Different studies have reported that the reduction of bark percentage decreases with tree size (Morhart et al. 2013), and thus the management alternatives of lengthening the rotation or reducing the stool density have been proposed. A reduction of nutrient concentrations with age has been previously reported for aspen (Rytter 2002), but considering a rotation longer than the 7 years considered in our study would be inoperative.

With the results of the present study, the management alternative more prone to savings of nutrient removal is the selection of efficient genotypes, even within a particular crossing. Nutrient efficient aspen clones have been identified, yielding a potential saving of 5\% of nutrients (Rytter and Stener 2003). As these authors did not find either significant relationships between nutrient concentrations and size, they suggested the possibility to select nutrient-efficient clones without significantly sacrificing genetic gain for growth. The most productive clone in this study (TRICHOBEL) show nutrient assimilation indices of 0.22, 2.94, 0.51, 0.63, 1.20, 2.86, 117, 49, 74, 27 and $600 \mathrm{Mg} \cdot \mathrm{kg}^{-1}$ for N, P, K, Ca, Mg, S, B, Mn, Fe, Zn and $\mathrm{Cu}$, respectively. Even so, with the results provided, it would be difficult to select a poplar clone more efficient for all macronutrients than the others belonging to the same crossing. It is also clear that low nutrient concentrations enhanced feedstock quality decreases the fouling and corrosion processes on furnace walls and increases the ash quality (Vega-Nieva et al. 2016).

The application of SRF to eucalypts leads to the removal of large amounts of nutrients, because harvesting in this case includes a rule the leaves, bark and branches, as long as wood (Guo et al. 2002; Eufrade et al. 2016). The data of this study for eucalypts in the age class $5-7$, even if the stand density is the usual one for pulp forest plantations (average density for these plots is 1120 trees $\mathrm{ha}^{-1}$ ) could be representative of the large amounts of nutrients removed if the whole tree is removed, as shown in Table 6 for an average yield of $6.5 \mathrm{Mg} \cdot \mathrm{ha}^{-1} \cdot \mathrm{year}^{-1}$. If compared to the poplar figures, these values means a similar amount of $\mathrm{N}$ or $\mathrm{K}$, but 3-4 times more $\mathrm{P}, \mathrm{Ca}$ and $\mathrm{Mg}$ removed per year to produce just $20 \%$ more biomass and less NAI, except for $\mathrm{N}$. As the soils are on average poorer than the poplar ones, these figures suppose the extraction of large percentages of available $\mathrm{P}$ and exchangeable $\mathrm{K}$ and $\mathrm{Ca}$ amounts. Eufrade et al. (2016) and Guo et al. (2002) reports average yearly removal rates well above the ones proposed in this study, along with consistently higher biomass yield. Sochacki et al. (2013) reported for E. globulus very similar rates of removal than the ones of this study.

\section{Conventional pulp plantations}

Study of biomass production, nutrient removal during logging operations and management of logging residues is essential to prevent negative effects on sustainable productivity and soil fertility in this management system (Gonçalves et al. 2013; Rubilar et al. 2018). Unlike the previous type of management, several commercial forestry operations leave different biomass compartments as logging residues in this case (Achat et al. 2015). The findings of this study confirms the importance of stem bark in terms of the $\mathrm{Ca}$ and $\mathrm{Mg}$ aboveground amounts of E. globulus, as removal at age 15 years would increase $32 \%, 24 \%, 39 \%, 225 \%$ and $254 \%$ if undebarked wood is removed from the forest. In the case of $E$. nitens, the ratios of $\mathrm{Ca}$ concentrations in bark related to wood found in this study were clearly higher for E. nitens (34.6) than for E. globulus (8.8), thus showing that the relevance of bark as an aboveground compartment storing $\mathrm{Ca}$ is more marked for E. nitens, as has been previously shown (Madgwick et al. 1981; Thiers et al. 2007). This reflects 
the recommendation to leave in place this biomass component, whose value as a product is only related to the generation of energy at the pulp factories. The present study findings indicate that the average rates of nutrient removal for a rotation of 15 years and harvesting exclusively the wood component are lower than the eucalypt SRF scenarios and similar $(\mathrm{N}, \mathrm{P}, \mathrm{Mg})$ or higher $(\mathrm{K}, \mathrm{Ca})$ than the poplar SRF scenario (Fig. 7). At this stage, the proportion of aboveground nutrients accumulated in the wood ranged between $33 \%$ for $\mathrm{Mg}$ till $51 \%$ for $\mathrm{K}$ and $\mathrm{N}$. These figures are higher than those reported by Hernández et al. (2009) when bark is left in place and similar to the ranges reported by Merino et al. (2005) for the same region. The percentage of nutrients found in the trunk of E. globulus (wood and bark) at the end of rotation in this study are similar to the ones reported for tropical plantations in the case of $\mathrm{N}, \mathrm{Ca}$ and $\mathrm{Mg}$, but higher for $\mathrm{K}$ and lower for $\mathrm{P}$ (Laclau et al. 2010; Rocha et al. 2016).

The recommendations for nutrient management should be based not only on the amount of nutrients removed at clearfelling, but also on the entire budget of inputs and outputs of nutrients, including the levels of soil supply needed to maintain production (Laclau et al. 2005). The information already available shows that the overall budgets may be negative if the parent materials have a low content of $\mathrm{Ca}$ and $\mathrm{Mg}$, the soil reserves are scarce, the rate of rainwater inputs are low and the stands have strong mineral uptake (Dambrine et al. 2000; Merino et al. 2005). The intensity of losses of non-acidic cations is directly related to the soil nutrient status and also to the management practices used (Madeira and Araújo 2015).

Age and genetic material directly affect the concentrations of nutrients in each component and, consequently, the estimation of nutrients removal, thus giving differences among different decisions in the management of these plantations. On the one hand, comparing the data of this study for clones and seedlings, the NAI, or cost per unit of wood yield in terms of two of the most limiting nutrients in the area ( $\mathrm{P}$ and $\mathrm{Ca}$ ) may therefore be reduced considerably ( 45 and $35 \%$ less, respectively) by using genetically improved material. The selection of genotypes with more efficiency in the use of nutrients has been applied for hybrid eucalypts in Brazil (Rosim et al. 2016). In a study carried out in Congo, Safou-Matondo et al. (2005) demonstrated the superiority of several clones of Eucalyptus urophylla regarding P $(+72 \%)$ and $\mathrm{Ca}(+43$ to $+59 \%$ ) assimilation index. Santana et al. (2002) indicated that as differences in NAI are also influenced by site parameters. Tree breeding programmes should therefore select genotypes with NAI compatible with natural soil fertility or with fertilization practices. NAI is a measure of the ability of plants to respond to fluctuating resource availability and has been shown to increase with nutrient availability (Santana et al. 2000). A limitation of the present study is therefore the lack of information of different eucalypt genotypes in the same site, even if seedlings plots were not apparently placed in sites more productive than the clonal plots. We have also to consider that the total amount of nutrients removed may be similar if more biomass is removed in the case of clones. With the overall data of this study, we estimate that clones are $14 \%$ more productive than seedlings at the same rotation age.

The influence of age on nutrient concentrations in tree parts, particularly for the wood component, provides an opportunity to lengthening the rotation to increase the biomass yield per unit of nutrient stored in the removed compartment. Such possibility can come along with decreases in mean annual increment of timber volume. The values shown were obtained for the set of plots used in this study (average site index slightly above the average for the region, $\mathrm{SI}=17 \mathrm{~m}$ ), and we have to consider that the pattern of mean annual increment depends on site productivity, peaking before for very productive sites. Negative trends of nutrient concentration with age were previously demonstrated by Laclau et al. (2000) for a hybrid eucalypt chronosequence or by Rocha et al. (2016). The influence of age on wood nutrient concentrations is due to the higher nutrient concentrations in the younger and more physiologically active tree tissues, leading to higher nutrient concentrations in sapwood than in heartwood (see Grove et al. 1996 for eucalypts and Augusto et al. 2008, for maritime pine). For Eucalyptus globulus in the Iberian Peninsula, heartwood of 9 years old trees has been shown to correspond to $17 \%-30 \%$ of the total tree volume (Gominho and Pereira 2000), showing that the sapwood component of the tree bole probably represents only the outer 7-8 years of tree growth. Older trees will have a narrow band of nutrient rich sapwood surrounding a relatively nutrient poor woody biomass enriched in carbon.

\section{Extensively managed stands of native species}

The results of this study show that for plots within the same region, nutrient concentrations were higher in aboveground biomass components of the native broadleaved species than in other species. This may be associated with the slightly better nutrient conditions in soils (Table 2). The concentrations determined in this study are higher than those reported for oak and birch by Hagen-Thorn et al. (2004). These authors observed relatively small differences between this pair of broadleaved species, although, as in the present study, the concentrations of $\mathrm{Mg}$ were higher in birch leaves than in oak leaves. The share of wood in the nutrient amounts found in this study are higher than the ones reported previously for oak in the same region (Balboa-Murias et al. 2006), as a result of the comparatively higher nutrient concentrations, particularly for Ca. An hypothetical clearfell with removal of wood, 
bark and thick branches would suppose the average annual removals lower than the other scenarios, except for $\mathrm{Ca}$, a result already shown previously (Gómez-García et al. 2016). The removals would represent a large proportion of the available nutrient contents in soils, indicating that, even in these species, care should be taken as to the biomass components removed and the felling pattern applied. As a result of a lower productivity (2.4 Mg.ha ${ }^{-1} \cdot \mathrm{year}^{-1}$ for oak and

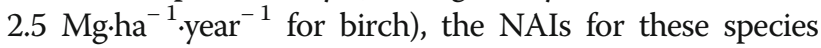
are much lower than for poplar or eucalypts in this study. This is not surprising if we consider that these native species are not specifically bred or managed to maximize biomass production. The removal of additional biomass components would increase the nutrient removal, and the harvesting methods and management of logging residues should therefore be adapted to the tree species and site fertility (Helmisaari and Kaarakka 2013).

\section{Conclusions}

Nutrient concentrations in biomass components varied with the component considered, plantation age (the concentrations of most nutrients, except $\mathrm{C}$, tended to decrease) and genetic material (several clones were more efficient regarding nutrient removal per unit of wood volume). $\mathrm{Nu}-$ trient sustainability was lower in SRF than in forest plantations, and it was lower in forest plantations than in natural stands. Poplar in SRF has the great advantage that the lifeless aboveground biomass can be removed.

\section{Additional file}

Additional file 1: Nutrient database. (XLSX 214 kb)

\section{Abbreviations}

ADP: Air dried pulp; ANCOVA: Analysis of covariance; BRT: Boosted regression trees; CEC: Cation exchange capacity; EDTA: Ethilenediaminetetraacetic acid; EU: European Union; MAl: Mean annual increment; MANR: Mean annual nutrient removal; MSE: Mean square error; NAl: Nutrient assimilation index; PASNR: Percent of available soil nutrients removed; RE: Renewable energy; SRF: Short rotation forestry; SWC: Specific wood consumption

\section{Acknowledgements}

The authors thank Prof. Gadow for encouraging the development of this study and to Dr. Diéguez-Aranda for providing oak and birch data.

\section{Funding}

Funding for this research was obtained from MINECO (Spain) through the project RTA2014-00007-C03-02. Additional funding was derived from the projects AGL2010-22308-C02-01 and AGL2007-66739-C02-01/FOR.

\section{Availability of data and materials}

Presented as an Additional file 1.

\section{Collection of plant samples}

The authors declare that the collection of plant samples was done according to the Spanish and European regulations with the required permissions.

\section{Authors' contributions}

RRS conceived the experiment, performed the analysis of data and lead the writing. CEF, JDGV, ARA and NO carried out the sampling and experiments.
EGG, FM, HS and CPC provided critical feedback and helped to shape the analysis and the manuscript. All authors read and approved the final manuscript.

\section{Authors' information}

RRS, HS, ARA lead the projects that provide the dataset used in this study.

Ethics approval and consent to participate

Not applicable.

\section{Consent for publication}

Not applicable.

\section{Competing interests}

TThe authors declare that they have no competing interests.

\section{Author details}

${ }^{1}$ Sustainable Forest Management Unit (UXFS), Department of Plant Production and Engineering Projects, Universidade de Santiago de Compostela (USC), Rúa Benigno Ledo, Campus Terra, 27002 Lugo, Spain.

${ }^{2}$ Centro de Investigación Forestal de Lourizán, Xunta de Galicia. Carretera de Marín km 3.5, 36153 Pontevedra, Spain. ${ }^{3}$ Sustainable Forest Management Unit (UXFS), Department of Agroforestry Engineering, Universidade de Santiago de Compostela (USC), Lugo, Spain. ${ }^{4}$ Universidad de Concepción, Facultad de Ciencias Forestales, Victoria, 631 Concepción, Chile. ${ }^{5}$ Forest Systems and Resources Department, Centre for Forest Research, INIA, Crta. de la Coruña km 7.5, 28040 Madrid, Spain.

Received: 30 April 2018 Accepted: 5 September 2018

Published online: 05 November 2018

\section{References}

Achat DL, Deleuze C, Landmann G, Pousse N, Ranger J, Augusto L (2015) Quantifying consequences of removing harvesting residues on forest soils and tree growth - a meta-analysis. For Ecol Manag 348:124-141. https://doi. org/10.1016/j.foreco.2015.03.042

Adegbidi HG, Volk T, White EH, Abrahamson LP, Briggs RD, Bickelhaupt DH (2001) Biomass and nutrient removal by willow clones in experimental bioenergy plantations in New York state. Biomass Bioenergy 20:399-411. https://doi.org/ 10.1016/S0961-9534(01)00009-5

André F, Jonard M, Ponette Q (2010) Biomass and nutrient content of sessile oak (Quercus petraea (Matt.) Liebl.) and beech (Fagus sylvativa L.) stem and branches in a mixed stand in southern Belgium. Sci Total Environ 408:22852294. https://doi.org/10.1016/j.scitotenv.2010.02.040

Angelsen A, Brockhaus M, Sunderlin WD, Verchot LV (2012) Analysing REDD+. Changes and choices. CIFOR, Bogor, p 426

Augusto L, Meredieu C, Bert D, Trichet P, Porté A, Bosc A, Lagane F, Loustau D, Pellerin S, Danjon F, Ranger J, Gelpe J (2008) Improving models of forest nutrient export with equations that predict the nutrient concentration of tree compartments. Ann For Sci 65:808. https://doi.org/10.1051/forest:2008059

Balboa-Murias M, Rojo A, Álvarez-González JG (2006) Carbon and nutrient stocks in mature Quercus robur L. stands in NW Spain. Ann For Sci 63:557-565. https://doi.org/10.1051/forest:2006038

R Core Team (2017) R: a language and environment for statistical computing. R Foundation for Statistical Computing, Vienna. https://www.R-project.org/. Accessed 30 Apr 2018.

Cruz Calleja AC (2005) Dinámica de nutrientes en parcelas experimentales de Populus x euramericana (Dode) Guinier "I-214". Tesis doctoral. Universidad Politécnica de Madrid. Escuela Técnica Superior de Ingenieros Agrónomos. http://oa.upm.es/328/1/ANA_CRUZ_CALLEJA.pdf. Accessed 30 Apr 2018

Dambrine E, Vega JA, Taboada T, Rodrigue L, Fernandez C, Macias F, Gras JM (2000) Bilans d'éléments minéraux dans de petits bassins versants forestiers de Galice (NW Espagne). Ann For Sci 57:23-38. https://doi.org/10.1051/forest:2000102

Díaz-Balteiro L, Rodríguez LC (2006) Optimal rotations on Eucalyptus plantations including carbon sequestration-a comparison of results in Brazil and Spain. For Ecol Manag 229:247-258. https://doi.org/10.1016/j.foreco.2006.04.005

Diéguez-Aranda U, Alboreca AR, Castedo-Dorado F, Gonzalez JGA, Barrio-Anta M, Crecente-Campo F, Gonzalez JMG, Perez-Cruzado C, Soalleiro RR, Lopez-Sanchez CA, Balboa-Murias MA, Varela JJG, Rodriguez FS (2009) Herramientas selvícolas para la gestión forestal sostenible en Galicia. Xunta de Galicia, pp 259 
Don A, Osborne B, Hastings A, Skiba U, Carter M, Drewer J, Flessa H, Freibauer A, Hyvonen N, Jones MB, Lanigan GJ, Mander U, Monti A, Djomo SN, Valentine J, Walter K, Zegada-Lizarazu W, Zenone T (2012) Land-use change to bioenergy production in Europe: implications for the greenhouse gas balance and soil carbon. GCB Bioenergy 4:372-391. https://doi.org/10.1111/j.1757-1707.2011.01116.x

Elias M, Potvin C (2003) Assessing inter- and intra-specific variation in trunk carbon concentration for 32 neotropical tree species. Can J For Res 33:1039-1045. https://doi.org/10.1139//03-018

Elith J, Leathwick JR, Hastie T (2008) A working guide to boosted regression trees. J Anim Ecol 77:802-813. https://doi.org/10.1111/.j.1365-2656.2008.01390.x

EU (2009) Directive 2009/28/EC of the European Parliament and of the Council of 23 April 2009 on the promotion of the use of energy from renewable sources and amending and subsequently repealing Directives 2001/77/EC and 2003/30/EC. O.J.o.t.E. Union (ed Union OjotE). EU, Brussels

Eufrade HJ, Melo RX, Sartori MMP, Guerra SPS, Ballarín AW (2016) Sustainable use of eucalypt biomass grown on short rotation coppice for bioenergy. Biomass Bioenergy 90:15-21. https://doi.org/10.1016/j.biombioe.2016.03.037

Friedman JH (2001) Greedy function approximation: a gradient boosting machine. Ann Stat 29:1189-1232

Giménez JC, Bertomeu M, Diaz-Balteiro L, Romero C (2013) Optimal harvest scheduling in Eucalyptus plantations under a sustainability perspective. For Ecol Manag 291:367-376. https://doi.org/10.1016/j.foreco.2012.11.045

Gómez-García E, Crecente-Campo F, Barrio-Anta M, Diéguez-Aranda U (2015) A disaggregated dynamic model for predicting volume, biomass and carbon stocks in even-aged pedunculate oak stands in Galicia (NW Spain). Eur J Forest Res 134:569-583. https://doi.org/10.1007/s10342-015-0873-3

Gómez-García E, Diéguez-Aranda U, Cunha M, Rodríguez-Soalleiro R (2016) Comparison of harvest-related removal of aboveground biomass, carbon and nutrients in pedunculate oak stands and in fast-growing tree stands in NW Spain. For Ecol Manag 365(1):119-127. https://doi.org/10.1016/jforeco.2016.01.021

Gominho J, Pereira H (2000) Variability of heartwood content in plantation-grown Eucalyptus globulus Labill. Wood Fiber Sci 32(2):189-195

Gonçalves JLD, Alvares CA, Higa AR, Silva LD, Alfenas AC, Stahl J, Ferraz SFD, Lima WDP, Brancalion PHS, Hubner A, Bouillet JPD, Laclau JP, Nouvellon Y, Epron D (2013) Integrating genetic and silvicultural strategies to minimize abiotic and biotic constraints in Brazilian eucalypt plantations. For Ecol Manag 301: 6-27. https://doi.org/10.1016/j.foreco.2012.12.030

González-García M, Hevia A, Majada J, Barrio-Anta M (2013) Above-ground biomass estimation at tree and stand level for short rotation plantations of Eucalyptus nitens (Deane \& Maiden) maiden in Northwest Spain. Biomass Bioenergy 54:147-157. https://doi.org/10.1016/j.biombioe.2013.03.019

Grove TS, Thomson BD, Malajczuk N (1996) Nutritional physiology of eucalypts: uptake, distribution and utilization. In: Attiwill PM, Adams MA (eds) Nutrition of eucalypts. CSIRO Publishing, Collingwood, pp 77-108

Guo LB, Sims REH, Horne DJ (2002) Biomass production and nutrient cycling in Eucalyptus short rotation energy forests in New Zealand. I: biomass and nutrient accumulation. Bioresource Technol 85:273-283. https://doi.org/10. 1016/S0960-8524(02)00118-9

Haberl H, Beringer T, Bhattacharya SC, Erb KH, Hoogwijk M (2010) The global technical potential of bio-energy in 2050 considering sustainability constraints. Curr Opin Env Sust 2:394-403. https://doi.org/10.1016/j.cosust. 2010.10.007

Hagen-Thorn A, Armolaitis S, Callesen I, Stjernquist I (2004) Macronutrients in tree stems and foliage: a comparative study of six temperate forest species planted at the same sites. Ann For Sci 61(6):489-498. https://doi.org/10.1051/ forest:2004043

Helmisaari H, Kaarakka L (2013) Nutrient management for sustainable production of energy biomass in boreal forests. In: Kellomaki S, Kilpelainen A, Alam A (eds) Forest bioenergy production. Springer, New York, pp 81-94

Hernández J, del Pino A, Salvo L, Arrarte G (2009) Nutrient export and harvest residue decomposition patterns of a Eucalyptus dunnii maiden plantation in temperate climate of Uruguay. For Ecol Manag 258:92-99. https://doi.org/10. 1016/j.foreco.2009.03.050

Hynynen J, Niemistö P, Viherä-Aarnio A, Brunner A, Hein S, Velling P (2009) Silviculture of birch (Betula pendula Roth and Betula pubescens Ehrh.) in northern Europe. Forestry 83(1):103-119. https://doi.org/10.1093/forestry/cpp035

IUSS Working Group WRB (2015) World Reference Base for Soil Resources 2014, update 2015. International soil classification system for naming soils and creating legends for soil maps. World soil resources reports no. FAO, Rome, p 106

Jenkins B, Baxter L, Miles T Jr, Miles T (1998) Combustion properties of biomass. Fuel Process Technol 54(1-3):17-46. https://doi.org/10.1016/S0378-3820(97)00059-3
Judd TS, Attiwill PM, Adams MA (1996) Nutrient concentrations in eucalypts: a synthesis in relation to differences between taxa, sites and components. In: Attiwill PM, Adams MA (eds) Nutrition of eucalypts. CSIRO Publishing, Collingwood, pp 123-153

Jug A, Hofmann-Schielle C, Makeschin F, Rehfuess KE (1999) Short-rotation plantations of balsam poplars, aspen and willows on former arable land in the Federal Republic of Germany. II. Nutritional status and bioelement export by harvested shoot axes. For Ecol Manag 121:67-83. https:/doi.org/10.1016/50378-1127(98)00558-1

Karvonen J, Halder P, Kangas J, Leskinen P (2017) Indicators and tools for assessing sustainability impacts of the forest bioeconomy. Forest Ecosystems 4:2. https://doi.org/10.1186/s40663-017-0089-8

Laclau JP, Bouillet JP, Ranger J (2000) Dynamics of biomass and nutrient accumulation in a clonal plantation of Eucalyptus in Congo. For Ecol Manag 128:181-196. https://doi.org/10.1016/S0378-1127(99)00146-2

Laclau JP, Ranger J, Deleporte P, Nouvellon Y, Saint-André L, Marlet S, Bouillet JP (2005) Nutrient cycling in a clonal stand of Eucalyptus and an adjacent savanna ecosystem in Congo: 3. Input-output budgets and consequences for the sustainability of the plantations. For Ecol Manag 210:375-391. doi: https://doi.org/10.1016/j.foreco.2005.02.028

Laclau JP, Ranger J, Gonçalves JLM, Maquère V, Krusche AV, M'Bou AT, Nouvellon Y, Saint-André L, Bouillet JP, Piccolo M, Deleporte P (2010) Biogeochemical cycles of nutrients in tropical Eucalyptus plantations. Main features shown by intensive monitoring in Congo and Brazil. For Ecol Manag 259:1771-1785. https://doi.org/10.1016/.jforeco.2009.06.010

Leite FP, Silva IR, Novais RF, Barros NF, Neves JCL, Villani EMA (2011) Nutrient relations during an eucalyptus cycle at different population densities. Rev Bras Cien Solo 35:949-959. https://doi.org/10.1590/S0100-06832011000300029

López G, Cañas I, Ruíz F (2010) Vegetative propagation techniques and genetic improvement in Eucalyptus globulus. In: Gil L, Tadesse W, Tolosana E, López R (eds) Eucalyptus species management, history, status and trends in Ethiopia. Proceedings from the congress held in Addis Abeba. September 15th-17th, p 2010

Madeira M, Araújo C (2015) Soil degradation risks and prevention measures in planted forests. The case of eucalyptus plantations in Portugal. In: González AA, Bengoetxea NG (eds) Soil degradation risks in planted forests. Servicio Central de Publicaciones del Gobierno Vasco, pp 107-117

Madgwick HAl, Beets P, Gallagher S (1981) Dry matter accumulation, nutrient and energy content of the above ground portion of 4-year-old stands of Eucalyptus nitens and E. fastigata. New Zeal J For Sci 11(1):53-59

Merino A, Balboa MA, Rodríguez-Soalleiro R, Álvarez-González JG (2005) Nutrient exports under different harvesting regimes in fast-growing forest plantations in southern Europe. For Ecol Manag 207:325-339. https://doi.org/10.1016/j. foreco.2004.10.074

Merino A, López AR, Brañas J, Rodríguez-Soalleiro R (2003) Nutrition and growth in newly established plantations of Eucalyptus globulus in northwestern Spain. Ann For Sci 60:509-517. https://doi.org/10.1051/forest:2003044

Morhart C, Sheppard J, Spiecker H (2013) Above ground leafless woody biomass and nutrient content within different compartments of a $P$. maximowicii $\times P$. trichocarpa poplar clone. Forests 4:471-487. https://doi.org/10.3390/f4020471

Oliveira N, Rodríguez-Soalleiro R, Pérez-Cruzado C, Cañellas I, Sixto H (2017) On the genetic affinity of individual-tree biomass allometry in poplar short rotation coppice. Bioenerg Res 10(2):525-535. https://doi.org/10.1007/s12155017-9818-7

Pérez-Cruzado C, Merino A, Rodríguez-Soalleiro R (2011) A management tool for estimating bioenergy production and carbon sequestration in Eucalyptus globulus and Eucalyptus nitens short rotation woody crops in North-Western Spain. Biomass Bioenergy 35(7):2839-2851. https://doi.org/10.1016/j. biombioe.2011.03.020

Pérez-Cruzado C, Mohren GMJ, Merino A, Rodríguez-Soalleiro R (2012) Carbon balance for different management practices for fast growing tree species planted on former pastureland in southern Europe: a case study using the CO2Fix model. Eur J For Res 131:1695-1716. https://doi.org/10.1007/s10342-012-0609-6

Pérez-Cruzado C, Rodríguez-Soalleiro R (2011) Improvement in accuracy of aboveground biomass estimation in Eucalyptus nitens plantations: effect of bole sampling intensity and explanatory variables. For Ecol Manag 261(11):2016-2028

Pérez-Cruzado C, Sánchez Ron D, Rodríguez-Soalleiro R, Hernández MJ, SánchezMartín MM, Cañellas I, Sixto H (2014) Biomass production assessment from Populus spp. short rotation irrigated crops in Spain. GCB Bioenergy 6(4):312-326. https://doi.org/10.1111/gcbb.12061

Ranger J, Turpault MP (1999) Input-output nutrient budgets as a diagnostic tool for sustainable forest management. For Ecol Manag 122:139-154. https://doi. org/10.1016/S0378-1127(99)00038-9 
Resquin F, Fariña I, Rachid C, Rava A, Doldán J (2012) Influencia de la edad de corte en el pulpeo de Eucalyptus globulus plantado en Uruguay. Agrociencia Uruguay 16(2):27-38

Ridgeway G (2017) gbm: generalized boosted regression models. R package version 2.1.3. https://cran.r-project.org/web/packages/gbm/gbm.pd. Accessed 30 Apr 2018

Rocha JHT, Gonçalves JLM, Gava JL, Godinho TO, Melo EASC, Bazani JH, Hubner A, Junior JCA, Wichert MP (2016) Forest residue maintenance increased the wood productivity of a Eucalyptus plantation over two short rotations. For Ecol Manag 379:1-10. https://doi.org/10.1016/j.foreco.2016.07.042

Rojo-Alboreca A, García-Villabrille JD, Pérez-Rodríguez F (2015) EucaTool ${ }^{\oplus}$, a cloud computing application for estimating the growth and production of Eucalyptus globulus Labill. Plantations in Galicia (NW Spain). Forest Systems 24(3). https://doi.org/10.5424/fs/2015243-07865

Rosim CC, Hsing TY, de Paula RC (2016) Nutrient use efficiency in interspecific hybrids of eucalypt. Rev Ciênc Agron 47(3):540-547. https://doi.org/10.5935/ 1806-6690.20160065

Rubilar RA, Allen HL, Fox TR, Cook RL, Albaugh TJ, Campoe OC (2018) Advances in silviculture of intensively managed plantations. Curr Forest Report 4:23-34 https://doi.org/10.1007/s40725-018-0072-9

Rytter $L$ (2002) Nutrient content in stems of hybrid aspen as affected by tree age and tree size, and nutrient removal with harvest. Biomass Bioenergy 23:13-25. https://doi.org/10.1016/S0961-9534(02)00029-6

Rytter L, Stener LG (2003) Clonal variation in nutrient content in woody biomass of hybrid aspen (Populus tremula L. $\times$ P. tremuloides Michx.). Silv Fenn 37(3): 313-324

Safou-Matondo R, Deleporte P, Laclau JP, Bouillet JP (2005) Hybrid and clonal variability of nutrient content and nutrient use efficiency in Eucalyptus stands in Congo. For Ecol Manag 210:193-204. https://doi.org/10.1016/j.foreco.2005. 02.049

San Miguel G, Corona B, Ruíz D, Landholmb D, Laina R, Tolosana E, Sixto I, Cañellas I (2015) Environmental, energy and economic analysis of a biomass supply chain based on a poplar short rotation coppice in Spain. J Clean Prod 94:93-101. https://doi.org/10.1016/j.jclepro.2015.01.070

Santana RC, Barros NF, Comerford NB (2000) Above-ground biomass, nutrient content, and nutrient use efficiency of eucalypt plantations growing in different sites in Brazil. New Zeal J For Res 30(1/2):225-236

Santana RC, Barros NF, Neves JCL (2002) Eficiência de utilização de nutrientes e sustentabilidade da produção em procedências de Eucalyptus grandis e Eucalyptus saligna em sítios florestais do Estado de São Paulo. Revista Árvore 26(4):447-457

Sixto H, Cañellas I, Arendonk J, Ciria P, Camps F, Sánchez M, Sánchez-González M (2015) Growth potential of different species and genotypes for biomass production in short rotation in Mediterranean environments. For Ecol Manag 354:291-299. https://doi.org/10.1016/j.foreco.2015.05.038

Sochacki SJ, Harper RJ, Smettem KJ, Dell B, Wu H (2013) Evaluating a sustainability index for nutrients in a short rotation energy cropping system. GCB Bioenergy 5:315-326. https://doi.org/10.1111/j.1757-1707.2012.01202.x

Soulères G (1984) Les peupliers forestiers. Revue Forestière Française XXXVI 6: 437-452

Tharakan PJ, Volk TA, Abrahamson LP, White EH (2003) Energy feedstock characteristics of willow and hybrid poplar clones at harvest age. Biomass Bioenergy 25:571-580. https://doi.org/10.1016/S0961-9534(03)00054-0

Thiers O, Gerding V, Schlatter JE (2007) Export of nitrogen and calcium through the thinning of a five-year-old stand of Eucalyptus nitens, Chile. Bosque 28(3): 256-262. https://doi.org/10.4067/S0717-92002007000300011

Thiffault E, Barrette J, Paré D, Titus BD, Keys K, Morris DM, Hope G (2014) Developing and validating indicators of site suitability for forest harvesting residue removal. Ecol Indic 43:1-18. https://doi.org/10.1016/j.ecolind.2014.02.005

Tullus A, Tullus H, Soo T, Pärn L (2009) Above-ground biomass characteristics of young hybrid aspen (Populus tremula L. $\times$ P. tremuloides Michx.) plantations on former agricultural land in Estonia. Biomass Bioenergy 33:1617-1625. https://doi.org/10.1016/j.biombioe.2009.08.001

Vanbeveren SPP, Gebauer R, Plichta R, Vola D, Ceulemans R (2016) Nutrients and energy in proleptic branches and leaves of poplar under a short-rotation coppice. Biomass Bioenergy 85:271-277. https://doi.org/10.1016/j.biombioe. 2015.12.016

Vega-Nieva DJ, Ortiz-Torres L, Míguez-Tabares JL, Morán J (2016) Measuring and predicting the slagging of woody and herbaceous mediterranean biomass fuels on a domestic pellet boiler. Energ Fuel 30(2):1085-1095. https://doi.org/ 10.1021/acs.energyfuels.5b02495
Viera M, Ruíz-Fernández F, Rodríguez-Soalleiro R (2016) Nutritional prescriptions for eucalyptus plantations: lessons learned from Spain. Forests 7:84. https://doi.org/10.3390/f7040084

Viera M, Schumacher MV, Caldeira MVW (2015) Biomassa e exportação de nutrientes pela colheita do eucalipto. In: Schumacher MV, Viera M (eds) Silvicultura do eucalipto no Brasil. Editora UFSM, Santa Maria

Wang D, Bormann FH, Lugo AE, Bowden RD (1991) Comparison of nutrient-use efficiency and biomass production in five tropical tree taxa. For Ecol Manag 46:1-21. doi: https://doi.org/10.1016/0378-1127(91)90241-M

\section{Submit your manuscript to a SpringerOpen ${ }^{\odot}$ journal and benefit from:}

- Convenient online submission

- Rigorous peer review

- Open access: articles freely available online

- High visibility within the field

- Retaining the copyright to your article

Submit your next manuscript at $\boldsymbol{\nabla}$ springeropen.com 